\title{
The potential therapeutic effect of stem cells loaded on two different vehicles (amniotic membrane and platelet rich plasma gel) in experimentally induced corneal alkali burns in rats
}

\section{Original Article}

Nesrine Ebrahim ${ }^{1}$, Ola M. Mohammed ${ }^{1}$, Arigue A. Dessouky ${ }^{2}$ and Dina Sabry \author{
Abdel Fatah ${ }^{3}$ \\ ${ }^{1}$ Department of Histology and Cell Biology, Faculty of Medicine, Banha University, Banha, \\ Egypt \\ ${ }^{2}$ Department of Histology and Cell Biology, Faculty of Medicine, Zagazig University, Zagazig, \\ Egypt \\ ${ }^{3}$ Department of Biochemistry, Faculty of Medicine, Cairo University, Cairo, Egypt
}

\begin{abstract}
Background: Corneal alkali burns are common ophthalmic emergencies which may lead to permanent visual impairment. In spite of great advances made in the treatment of these cases, the structural and functional restoration of corneal alkali burns remains challenging. Bone marrow-derived mesenchymal stem cells (BM-MSCs) have been demonstrated to enhance corneal healing. However the problem remains in finding a suitable vehicle to deliver BM-MSCs to the site of injury.

Objectives: To evaluate the therapeutic potential of BM-MSCs loaded on two biological vehicles (amniotic membrane versus platelet-rich plasma gel) in corneal alkali burns.

Materials \& Methods: Fifty rats were randomly divided into five equal groups. Group I (control group), group II (corneal ulcer group) and group III (recovery group). Group IV rats with corneal ulcers were treated with amniotic membrane loaded with BM-MSCs while in the group V the rats with corneal ulcers were treated with platelet-rich plasma cells loaded with BMMSCs. The corneal specimens were processed for the light microscope, transmission electron microscope examination, and RT qPCR assay for VEGF and iNOS.

Results: Group II showed epithelial separation and denudation with disorganized stroma and disrupted Descemet's membrane and endothelium. Group III showed residual epithelial separation and vacuolation with neovascularization of the disorganized stroma. Group IV showed thinning of corneal epithelium with inflammatory infiltration of the stroma. Group V corneas revealed restoration of corneal epithelial thickness, organized stroma and continuous Descemet's membrane. Also, there was an upregulation of iNOS \& VEGF gene expression in groups II and III which was downregulated in group IV and V.

Conclusions: The combination of BM-MSCs with PRP gel was a promising treatment for corneal alkali burns and may be applicable for other types of corneal disorders.
\end{abstract}

Key Words: Amniotic membrane, BM- MSCs, Corneal alkali burn, PRP

Revised: 22 July 2017, Accepted: 29 September 2017

Corresponding Author: Nessrrine Ebrahim Salem, Department of Histology and Cell Biology, Faculty of Medicine, Banha University, Banha, Egypt, Tel.: 0552345209, E-mail: nessrrineebrahim@yahoo.com

ISSN: $1110-0559$, Vol. 40, No. 4

\section{INTRODUCTION}

Globally, ten million individuals suffer from bilateral visual impairment due to corneal affection. Corneal lesions represent the second most common cause of diminution of vision after cataract ${ }^{[1]}$. Most corneal lesions are associated with neovascularization, such as aniridia, infection, inflammation and mechanical or chemical injuries ${ }^{[2]}$.

Corneal alkali burns are an opthalmic crisis commonly seen among 20 to 40 year old males working in chemical laboratories and factories. Due to the young age of patients, possible long term disabilities following ocular burns could adversely impact patients' lives ${ }^{[3]}$.

The treatments of the corneal alkali burns incorporate medical and surgical modalities ${ }^{[4]}$. Many cases require surgical intervention, especially limbal stem cells (LSCs) transplantation. This is conceivable in one-sided lesions when the other-side cornea is healthy or less harmed. However, this carries a possible risk of LSC depletion in the healthy donor eye. Allogeneic limbal stem cells have been directed by various ophthalmologists, in many cases, however, the results were not sufficient and treatment requires delayed immunosuppressive treatment ${ }^{[5]}$. Alternative sources of cells include; conjunctival cells, buccal mucosal cells, embryonic undifferentiated stem cells ${ }^{[6]}$, induced pluripotent stem cells and mesenchymal stem cells ${ }^{[7]}$ have been explored for generation of the limbal trans-differentiation.

Along these lines, mesenchymal stem cells (MSCs) seem to speak to the most encouraging cell source to 
replace LSCs $^{[8]}$. Bone marrow- derived mesenchymal stem cells (BM-MSCs) are multipotent stromal cells which can differentiate into various types of cells. thus representing are a promising source for cellular treatment. Lastly, MSCs have been examined for the healing of corneal alkali burn with promising results. Transplanted MSCs are thought to enhance corneal regeneration through excretion of antiinflammatory and anti-angiogenic cytokines ${ }^{[9]}$.

However, one of the real issues related to stem cells treatment remains the absence of a reasonable vehicle to transport SCs to the exact tissue site. Up until this point, different material and scaffolds have been examined for the transfer of SCs ${ }^{[10]}$.

Human amniotic membrane (AM) represented the best standard in ocular surfaces reconstruction. In most of the studies, AM alone, helped in slower corneal healing, which leads to the conjunctival epithelial invasion but BMSCs loaded on AM is superior to AM alone for repair of corneal ulcer $^{[11]}$.

Platelet-rich plasma (PRP) contains a high convergence of vital growth factors and cell adhesion molecules. These cell adhesion molecules and growth factors possess a major role in wound regeneration and improves the physiological microenvironment at the site of the injury or the surgery ${ }^{[12]}$.

\section{MATERIALS AND METHODS}

\section{Experimental Animals}

Fifty healthy adult male albino rats weighing about 200 grams were bred and maintained in an air-conditioned animal house with specific pathogen-free conditions. Rats were subjected to a normal light/dark cycle and allowed unlimited access to chow and water. All animals' procedures were performed according to approved protocols of the Animal Committee of the Faculty of Medicine, Benha University and in accordance with the recommendations for the proper care and use of laboratory animals.

\section{Experimental procedure}

Rats were randomly divided into equal five groups $(\mathrm{N}=10)$ :

Group I (control group): the cornea of right eyes were treated with normal saline.

Group II (corneal ulcer group): corneal alkali burn was induced in the right eyes by sodium hydroxide $(\mathrm{NaOH})$. Rats were sacrificed 3 days post- alkali burn to assess the alterations of the histological structure which occurred in acute phase of corneal alkali burn.

Group III (recovery group): corneal alkali burn was induced in the right eyes by sodium hydroxide $(\mathrm{NaOH})$. Rats were sacrificed 28 days post- alkali burn to assess the recovery.
Group IV (BM-MSC/AM group): corneal alkali burn was induced in the right eyes then treated locally after 3 days by BM- MSCs loaded on amniotic membrane. Rats were sacrificed after 28 day post alkali burn.

Group V (BM-MSC/PRP group): The corneal alkali burn was induced in the right eyes then treated after 3 days by BM-MSCs loaded on PRP gel. Rats were sacrificed 28 days post- alkali burn.

\section{Corneal alkali-burn model}

Rats were anesthetized by intramuscular injection of $0.5 \mathrm{mg} / \mathrm{kg}$ ketamine. Thereafter, corneal alkali burns were induced on the right eye of each rat, while the other eye was left without burns to enable the animals to access water and food, as well as to move freely. A filter paper of $5 \mathrm{~mm}$ diameter was soaked for 30 seconds in $1 \% \mathrm{NOH}$ and was applied on the whole cornea including the limbus for 25 seconds, then the cornea was rinsed with $10 \mathrm{ml}$ of distilled water. All groups received local antibiotic, as levofloxacin eye drops, administered twice per day throughout the duration of the experiment ${ }^{[13]}$.

At the end of the experimental duration, rats were anesthetized with intramuscular injection of $0.5 \mathrm{mg} / \mathrm{kg}$ of ketamine, then the right eyes were carefully enucleated and the excised, corneas were processed for histological (light and transmission electron microscope) examination as well as RNA extraction for real time PCR assay.

\section{Preparation of BM-MSCs}

Rats BM-MSCs were prepared in the Biochemistry Department, Faculty of Medicine, Cairo University. Bone marrow cells were flushed from tibia and fibula of rat bones with phosphate-buffered saline (PBS) containing 2 $\mathrm{ml}$ EDTA. Over $15 \mathrm{ml}$ Ficoll-Paque (Gibco-Invitrogen, Grand Island, NY), $35 \mathrm{ml}$ of the diluted sample was carefully layered, centrifuged for 35 minutes at $400 \mathrm{rpm}$ and the upper layer was aspirated leaving undisturbed mononuclear cell (MNC) layer at the interphase. This MNC layer was aspirated, washed twice in PBS containing $2 \mathrm{ml}$ EDTA and centrifuged for 10 minutes at $200 \mathrm{xg} \mathrm{rpm}$ at $10^{\circ} \mathrm{C}$. The cell pellet was re-suspended in a final volume of $300 \mu \mathrm{l}$ of buffer. Isolated MSCs were cultured on 25 $\mathrm{ml}$ culture flasks in minimal essential medium (MEM) supplemented with $15 \%$ fetal bovine serum (FBS) and incubated for 2 hours at $37^{\circ} \mathrm{C}$ and $5 \% \mathrm{CO}_{2}$. Adherent BM-MSCs were cultured in MEM supplemented with $30 \% \mathrm{FBS}, 0.5 \%$ penicillin, streptomycin and at $37^{\circ} \mathrm{C}$ in $5 \% \mathrm{CO}_{2}$ in air (14). All cultures were examined using an inverted microscope; Leica DM IL LED with camera Leica DFC295 (Leica Microsystems CMS GmbH, Ernst-LeitzStraße 17-37, Wetzlar, D-35578, Germany). 


\section{Preparation of Amniotic membrane}

\section{Amniotic membrane collection}

Amniotic membranes (AMs) were collected from full term delivery women with informed consent at Benha University hospital. At the end of the normal delivery and after complete separation of the placenta, the placentas were collected under complete aseptic conditions.

\section{Amniotic membrane preparation}

The AMs were stripped off and immersed in $1 \mathrm{~L}$ sterile normal saline containing $100 \mu / \mathrm{ml}$ penicillin and $0.2 \mathrm{mg} /$ $\mathrm{ml}$ streptomycin and $0.025 \mathrm{mg} / \mathrm{ml}$ amphotericin. The epithelial surface was marked by external knot of silk stitch which was placed on the surface of the AMs. Tentime serial washing of the membranes in sterile petri dishes containing $20 \mathrm{ml}$ normal saline with the former additives were done. During washing, each individual membrane was finger rubbed and squeezed of blood vessels gently. AMs were then kept in a container of normal saline with additives for a period of two hours in a refrigerator ${ }^{[15]}$.

\section{Amniotic membrane banking}

The AMs were uniformly spread without folds or tears on individually sterilized $0.22 \mathrm{~m}$ nitrocellulose membranes of the required size $(47 \mathrm{~mm})$ with epithelial/basement layer surface up. The molded membrane sheets were cut into 4-5 $\mathrm{cm}$ pieces, each piece was placed in sterile plastic dishes containing the preservative medium 1:1 vol/vol ratio sterile glycerol and Dulbcus Modified Eagles media (DMEM, Sigma-Aldrich Chemical Co., St. Louis, Missouri, USA) with $3.3 \%$ L-glutamine, $25 \mu \mathrm{g} / \mathrm{ml}$ gentamicin, 50 units/ $\mathrm{ml}$ penicillin, $100 \mu \mathrm{g} / \mathrm{ml}$ ciprofloxacin and $0.5 \mathrm{mg} / \mathrm{ml}$ amphotericin B. The membranes were then preserved at a temperature of $-80^{\circ} \mathrm{C}^{[16]}$.

\section{Amniotic membrane assessment}

The AMs were assessed bacteriologically and mycological through direct microscopic examination (swabbing and staining) with additional aerobic and anaerobic culturing immediately after collection. Samples of the cryopreserved AMs were tested one, two and three weeks after preservation using the same previously mentioned procedures to detect any bacterial or fungal contamination during preservation. The cryopreserved AMs were allowed to thaw at room temperature before use $^{[16]}$.

\section{Loading of stem cells on amniotic membrane.}

Under complete aseptic condition; the previously prepared cryopreserved AMs were washed with phosphate buffer saline containing antibiotic several times till they become free from preservative glycerol. The isolated, propagated and characterized BM-MSCs for two weeks in culture were counted with haemocytometer and then loaded on AMs as a feeder layer. AMs co-cultured with BM-MSCs were maintained in RPMI-1640 media for one week and supplemented with $10 \%$ fetal bovine serum (FBS; USDA, Gibco, Grand Island, NY, USA), antibiotics (penicillin 10000-U/ml, streptomycin 10000-U/ml) and amphotericin-B 25-U/ml MSCs. Co-culture was incubated at $37^{\circ} \mathrm{C}$ in a humidified atmosphere containing $5 \% \mathrm{CO}_{2}{ }^{[17]}$.

\section{Preparation of platelet rich plasma}

Whole blood samples were collected using acceptable medical techniques to avoid hemolysis. $30 \mathrm{cc}$ venous bloods was obtained by venipuncture from the same rats and added in acid citrate dextrose (ACD) tubes. Samples were sent for laboratory analysis for platelet concentration before centrifugation. The blood was centrifuged first using a 'soft' spin at $1480 \mathrm{rpm}$ for 6 minutes to separate erythrocytes. The supernatant plasma containing platelets was transferred into another sterile tube without anticoagulant. The tube was centrifuged secondly at a higher speed of $3400 \mathrm{rpm}$ for 15 minutes 'hard spin' to obtain a platelet concentrate. The lower $1 / 3$ rd was platelet rich plasma (PRP) and the upper 2/3rd was platelet poor plasma (PPP). At the bottom of the tube, platelet pellets were formed. PPP was removed and the platelet pellet was suspended in a minimum quantity of plasma $(2-4 \mathrm{ml})$ by gently shaking the tube ${ }^{[18]}$.

\section{Preparation of PRP gel}

Platelets were activated with thrombin (Sigma, St. Louis, MO USA) $5 \mathrm{U} / \mathrm{mL}$ in $40 \mathrm{ml} \mathrm{CaCl} 2$ ): $10 \mu \mathrm{L}$ of PRP and $10 \mu \mathrm{L}$ of thrombin was mixed and incubated at $37^{\circ} \mathrm{C}$ for 30 minutes to form PRP gel. Then loading of stem cells on PRP membrane just before application on injured eyes ${ }^{[19]}$.

\section{Histological study (light and electron microscopy)}

For light microscopic study (H\&E staining and immunohistochemistry)

Right corneas were excised. Specimens were fixed in $10 \%$ buffered formol saline and processed for paraffin sections of 4-6 $\mu \mathrm{m}$ thickness, mounted on glass slides for $H \&$ E (20). Other sections were mounted on +ve charged slides for immunohistochemical staining using monoclonal PCNA at 1:400 dilution (Sigma-Aldrich, St Louis, Missouri, USA). Antigen retrieval was performed in all cases by steam heating the slides in a 1-mmol/L solution of EDTA $(\mathrm{pH}$ 8.0) for 30 minutes. After blocking of endogenous biotin, staining was performed using an automated immunostainer followed by using a streptavidin-biotin detection system (Dako, Glostrup, Denmark). Sections were counterstained with hematoxylin. As a negative control, the primary antibody was replaced with PBS $^{[21]}$.

\section{Morphometric study}

The mean area percent of PCNA expression was quantified five images from in five non-overlapping fields 
from each rat of each group using Image-Pro Plus program version 6.0 (Media Cybernetics Inc., Bethesda, Maryland, USA).

\section{For transmission electron microscopic study}

Specimens of right corneas $(1 \mathrm{~mm} 3)$ were fixed with $2.5 \%$ buffered glutaraldehyde in $0.1 \mathrm{M}$ PBS (phosphate buffer solution) $\mathrm{pH} 7.4$ at $4^{\circ} \mathrm{C}$ for $2 \mathrm{~h}$. Then, they were washed three times with PBS 10 minutes each. Post fixation in $1 \%$ Osmic acid for 30 minutes. Washing three times with PBS 10 minutes each, then dehydrated with ascending series of ethyl alcohol $(30,50,70,90 \%$ and absolute alcohol) each concentration for 30 minutes. Thereafter, they were infiltrated with acetone for 1 hour. After dehydration samples were embedded in Araldite 502 resin. The plastic molds were cut in the LEICA Ultracut (UCT ultra-microtome), and stained with $1 \%$ Toluidine blue. After examination of semi-thin sections, ultra-thin sections (50-60 nm in thickness) were cut, stained with uranyl acetate, then counter stained with lead citrate. The sections were examined and photographed using JEOLJEM-100 SX electron microscope, Japan, at the Electron Microscope Unit in Tanta University ${ }^{[22]}$.

\section{Reverse Transcriptase quantitative PCR (RT-qPCR)}

The corneas of all studied groups were homogenized and total RNA were isolated with RNeasy Mini Kit (Qiagen, Hilden, Germany) and further analyzed for quantity and quality with a dual beam spectrophotometer (Beckman Coulter, Fullerton, California, USA). For quantitative expression of vascular endothelial growth factor (VEGF) and nitric oxide synthase (iNOS) genes; the following procedure was performed. $200 \mathrm{ng}$ of the total RNA from each sample were used for cDNA synthesis by reverse transcription using High capacity cDNA Reverse Transcriptase kit (Applied Biosystems Inc., Foster City, CA, USA). The cDNA was subsequently amplified with the Syber Green One-Step PCR Master Kit in a 48-well plate (Applied Biosystems Inc., Foster City, CA, USA) as follows: 10 minutes at $95^{\circ} \mathrm{C}$ for enzyme activation followed by 40 cycles of 15 seconds at $95^{\circ} \mathrm{C}, 20$ seconds at $55^{\circ} \mathrm{C}$ and 30 seconds at $72^{\circ} \mathrm{C}$ for the amplification step. Changes in the expression of each target gene were normalized relative to the mean critical threshold (CT) values of GAPDH housekeeping gene by the $2^{-\Delta \Delta C} \mathrm{t}$ method (23). We used $1 \mu$ of both primers specific for each target gene. Primers sequence specific for each gene demonstrated in table (1).

\section{Statistical analysis}

Data collected from the experiment was recorded and analyzed using IBM SPSS Statistics software for Windows, Version 20 (IBM Corp., Armonk, NY, USA). One-way analysis of variance (ANOVA) with Post Hoc LSD test was used to compare differences among the groups of quantitative genes expression. In each test, the data was expressed as the mean (M) value, standard deviation
(SD) and differences were considered to be significant at $p<0.01$.

\section{RESULTS}

\section{BM-MSCs identification}

The BM-MSCs were identified after 2 weeks in culture with an inverted microscope as spindle shaped cells (Fig. 1a). Their phenotypes were confirmed by flow cytometry and analysis of cell surface molecules for CD90 and CD29 (Fig. 1b). The BM-MSCs loaded on amniotic membrane appeared spindle shaped under inverted microscope (Fig. 1c).

\section{Histological results}

\section{Hematoxylin \& Eosin results}

Group I (control group): H\&E stained sections showed the layers of the cornea. The non-keratinized stratified squamous epithelium consisted of five to seven layers of cells resting on a uniform basement membrane; while the Bowman's membrane was not observed. The epithelium consisted of a single basal layer of high cuboidal to columnar cells, intermediate layers of polygonal cells, and superficial layers of squamous cells. The stroma forming most of corneal thickness was formed of regularly arranged collagen fibers with the spindle shaped nuclei of small keratocytes. The Descemet's membrane appeared homogenous, acidophilic and covered by Descemet's endothelium (Fig. 2a).

Group II (corneal ulcer group): The sections taken 3 days after induction of corneal ulcers showed various degrees of corneal epithelial affection. Some areas revealed separation of superficial epithelial cells while other areas showed complete denudation of the epithelium and separation of the epithelium from the underlying stroma. The stromal collagen fibers were disorganized with wide spaces. The Descemet's membrane and endothelium appeared disrupted (Fig. 2b). Group III (recovery group): The sections revealed disorganized, disfigured epithelium with marked thinning of the corneal epithelium compared with the control group and vacuolization of its cytoplasm observed. The upper part of stroma consisted of thin disorganized collagen fibers with wide spaces in between while the lower part showed regularly arranged collagen fibers with numerous small spaces. Neovascularization of the stroma was also noticed. Descemet's membrane and endothelium appeared continuous (Fig. 2c).

Group IV (BM-MSC/AM group): The sections revealed thinning of corneal epithelium. Some epithelial cells showed vacuolated cytoplasm. Wide spaces between the collagen fibers of the stroma were seen. The Descemet's membrane and endothelium appeared 
comparable to those of the control group (Fig. 2d). Group V (BM-MSC/PRP gel group): revealed that the corneal epithelium was nearly uniform thickness with absence of epithelial loss or discontinuity. The epithelial cells were comparable to those of control with intact basement membrane. The stroma showed regular collagen fibers and spindle shaped nuclei of keratocytes. The Descemet's membrane and the endothelium appeared similar to the control group (Fig. 2e).

\section{Immunohistochemical results}

To assess the proliferation of corneal cells after MSC transplantation, PCNA immunostaining was used and gave nuclear reaction. PCNA was expressed not only in the basal epithelial layer, but also extended from the periphery of the corneal epithelium to the central regenerated corneal epithelium in Group IV and $\mathrm{V}$ (Fig. 3d \& 3e). PCNA expression was much more pronounced on day 28, while the expression of PCNA was minimal in group I (Fig. 3a), mild in group II (Fig. 3b) and moderate in group III (Fig. 3c).

The mean area percent of PCNA for all groups was represented in Tables 2 and Figure 3f. There was a significant increase in mean area percent of PCNA immuno-expression of groups IV, V compared with group II.

\section{Transmission electron microscope results:}

Group I (control group): The superficial layers of epithelium were formed of squamous cells with flattened euchromatic nuclei. The cells were connected by desmosomes (Fig. 4a). The intermediate layers consisted of polygonal cells with round euchromatic nuclei and numerous mitochondria in their cytoplasm. Electron dense desmosomes connected the adjacent cells (Fig. 4b). The basal layers were formed of columnar cells with regular euchromatic nuclei and mitochondria in the cytoplasm. The basal layer of the corneal epithelium was columnar with regular euchromatic nuclei and numerous mitochondria in the cytoplasm. The cells rested on a regular basement membrane (Fig. 4c). The stroma was formed of regularly arranged collagen fibrils showing orthogonal arrangement. Spindle shaped keratocytes were seen among the collagen fibrils with euchromatic nuclei and cytoplasmic organelles (Fig. 4d). The Descemet's membrane appeared homogenous between the stroma and the endothelium. The endothelium was flattened with euchromatic nuclei and the cytoplasm contained variable sized pinocytotic vesicles (Fig. 4e).

Group II (corneal ulcer group): Squamous cells of the superficial layer had shrunken nuclei and separated by wide intercellular spaces with inflammatory cells infiltration among them (Fig. 5a). The separation was also observed among the irregular cells of the intermediate and basal layers. Their nuclei showed various degenerative changes ranging from irregularity to shrinkage and condensation of chromatin. The cells were also infiltrated by numerous inflammatory cells. The basal basement membrane appeared interrupted and inflammatory cells were observed in the stroma (Fig. 5b and 5c). The stroma showed disorganization of collagen fibrils and wide spacing in between, with numerous inflammatory cells. The keratocytes possessed irregular heterochromatic nuclei and vacuolated cytoplasm (Fig. 5d). The Descemet's membrane and endothelium appeared attenuated and interrupted. The endothelial cells showed rarified cytoplasm (Fig. 5e).

Group III (recovery group): The sections showed wide intercellular spaces separating the cells of the 3 epithelial layers which contained irregular nuclei while others where shrunken and heterochromatic. Their cytoplasm displayed multiple vacuoles and mitochondria with disrupted cristae (Fig. 6a, 6b and 6c). The epithelial cells were rested on an irregular basement membrane. The upper part of stroma consisted of disorganized collagen fibrils and inflammatory cells. Some keratocytes showed irregular euchromatic nuclei while other nuclei were irregular and heterochromatic. The lower part of the stroma showed regular arrangement of collagen fibrils. The keratocytes had irregular contours and nuclei. The cells were surrounded by areas devoid of collagen fibrils (Fig. 6d and 6e). Additionally, many dilated blood vessels with heterochromatic endothelial lining and surrounded by inflammatory cells were observed in the stroma (Fig. 6f).The endothelial cells showed separation from the underlying Descemet's membrane (Fig. 6g).

Group IV (BM-MSC/AMs group): The superficial squamous cells showed euchromatic nuclei comparable to those of the control group. Minimal intercellular spaces were observed and desmosomes were seen connecting the cells to each other (Fig. 7a). Cells of the intermediate layer were still irregular and separated by wide intercellular spaces. Their nuclei appeared indented by cytoplasmic vacuoles and numerous mitochondria with disrupted cristae were also noticed in the cytoplasm (Fig. 7b). Cells of the basal layer were seen resting on regular basement membranes and appeared similar to those of the control group. The cells were connected to each other by desmosomes with minimal intercellular spaces. The nuclei appear irregular and the cytoplasm contains numerous mitochondria (Fig. 7c). The collagen fibers of the stroma revealed few wide spaces, the keratocytes showed large vacuoles in their cytoplasm (Fig. 7d). The Descemet's endothelium revealed mitochondria with disrupted cristae (Fig. 7e).

Group V (BM-MSC/PRP gel group): Ultrathin sections revealed corneal histology similar to that of the control group. The corneal epithelium showed normal nuclear and cytoplasmic configuration with the adjacent cells connected by desmosomes and resting on a slightly irregular basement membrane (Fig. 8a, 8b and 8c). The stroma showed regular collagen fibrils with orthogonal 
arrangement. The keratocytes appeared spindle shaped with euchromatic nuclei among the collagen fibrils (Fig. $8 \mathrm{~d})$. The Descemet's membrane was homogenous and the endothelial cells were nearly similar to the control group (Fig.8e).

\section{Quantitative Gene Expression}

The expression of VEGF was very low in healthy control corneas. Three days after corneal alkali burn, the expression of VEGF was high but after 28 days in the recovery group the expression was very high. The treatment of injured corneas with BM-MSCs loaded on AM reduced VEGF expression. The highest reduction of VEGF expression was seen in corneas treated with BMMSCs loaded on PRP gel.

Table 1: Primers sequence specific for each gene.

\begin{tabular}{lcc}
\hline Target gene & Primer sequence: 5' $^{\prime}-3^{\prime}$ & Gene bank accession number \\
\hline VEGF & Forward: CTATTCTGTCAGCACTTTGG & NM_031054.2 \\
& Reverse: CAGACTTTGGTCTCCAACTT & \\
Inos & Forward: AAATGTGGGTGTACACAGGC & NM_031055.1 \\
& Reverse: TTCACCCGGTTGTGGAAACT & NG028301.2 \\
GAPDH & Forward: CACCCTGTTGCTGAGCCATATTC & \\
& Reverse: GACATCAAGAAGGTGGTGAACAG
\end{tabular}

a: Significant difference $(p<0.01)$ compared with control group.

b: Significant difference $(p<0.01)$ compared with group II.

c: Significant difference $(p<0.01)$ compared with group III.

d: Significant difference $(p<0.01)$ compared with group IV.

e: Significant difference $(p<0.01)$ compared with group V.

Table 2: Showing the mean (M) of PCNA immuno-expression for all groups.

\begin{tabular}{|c|c|c|c|c|c|}
\hline & Group I & Group II & Group III & Group IV & Group V \\
\hline PCNA & $118.67 \pm 3.3$ & $121.67 \pm 4,2$ & $122.83 \pm 5.6$ & $173 \pm 3.1^{\text {abce }}$ & $198.5 \pm 2.9^{\mathrm{abcd}}$ \\
\hline $\begin{array}{l}\text { VEGFR2 gene } \\
\text { expression }\end{array}$ & Control group & Ulcer group & Recovery group & AM group & PRP group \\
\hline Mean & 0.25 & 1.04 & 1.17 & 0.56 & 0.37 \\
\hline $\mathrm{SD}$ & 0.11 & 0.10 & 0.06 & 0.18 & 0.14 \\
\hline $\begin{array}{l}\text { Significance } \\
\text { at }<0.001\end{array}$ & $2,3,4$ & $1,4,5$ & $1,4,5$ & $1,2,3,5$ & $2,3,4$ \\
\hline
\end{tabular}

Table 4: Showing the mean (M), SD of iNOS gene expression for all groups.Tem porur lost es renint patilissolis re

\begin{tabular}{|c|c|c|c|c|c|}
\hline $\begin{array}{l}\text { INOS gene } \\
\text { expression }\end{array}$ & Control group & Ulcer group & Recovery group & AM group & PRP group \\
\hline Mean & 0.0 & 1.38 & 1.57 & 0.48 & 0.37 \\
\hline SD & 0.0 & 0.40 & 0.40 & 0.25 & 0.04 \\
\hline $\begin{array}{l}\text { Significance } \\
\text { at }<0.001\end{array}$ & $2,3,4,5$ & $1,4,5$ & $1,4,5$ & $1,2,3$ & $1,2,3$ \\
\hline
\end{tabular}




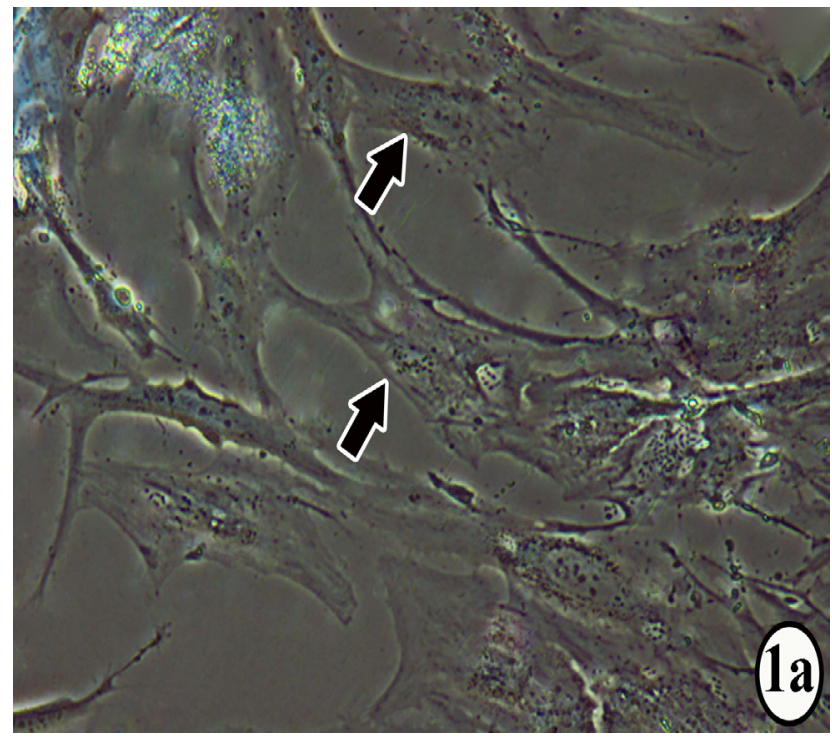

Fig. 1a: An inverted microscope micrograph on day 15 from a primary culture of BM-MSCs showing many spindle shaped stem cells (arrows).
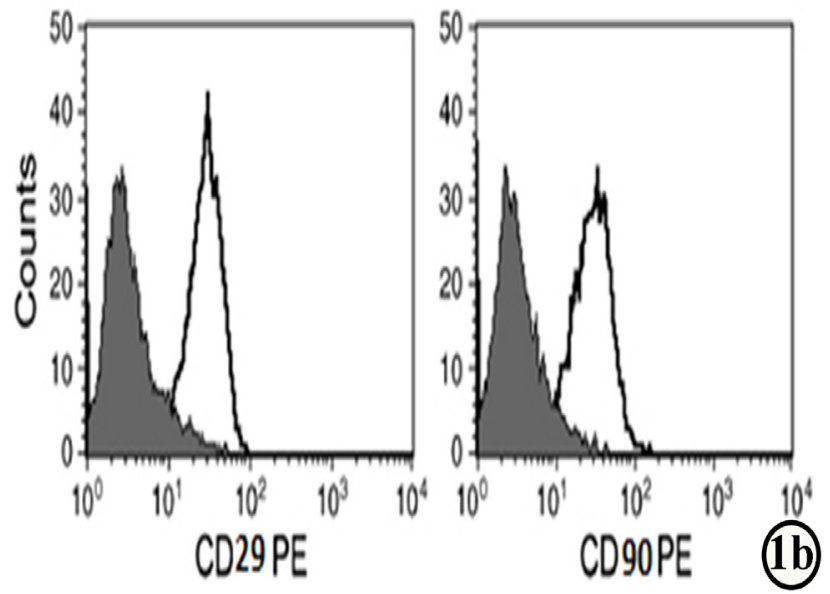

Fig. 1b: Flow cytometric chart analysis of surface antigens of BM-MSCs. They were positive for CD29 and negative CD90.

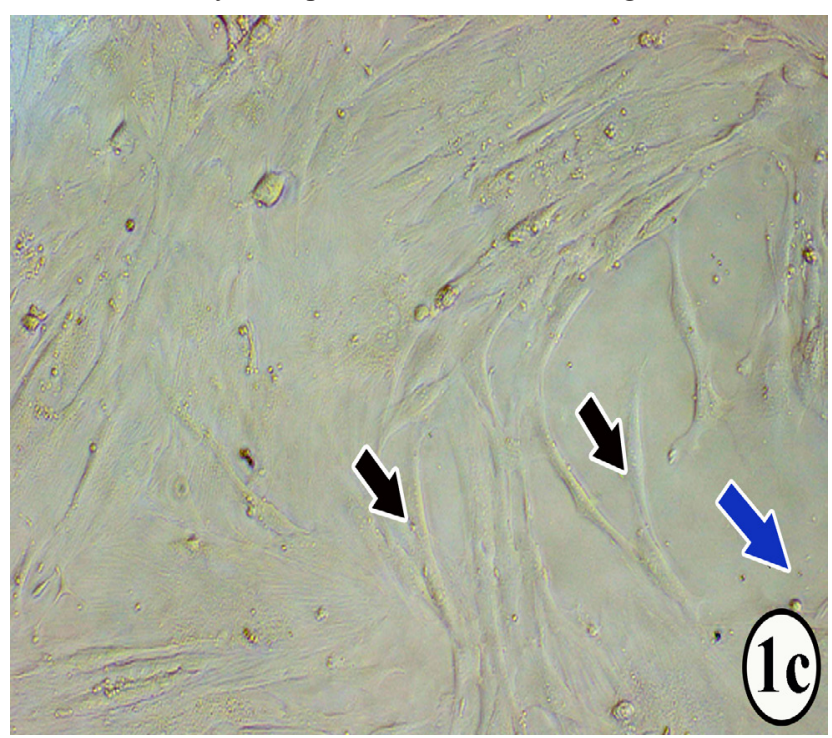

Fig. 1c: showing spindle shaped BM-MSCs (black arrows) loaded on amniotic membrane (blue arrow).

(X200).

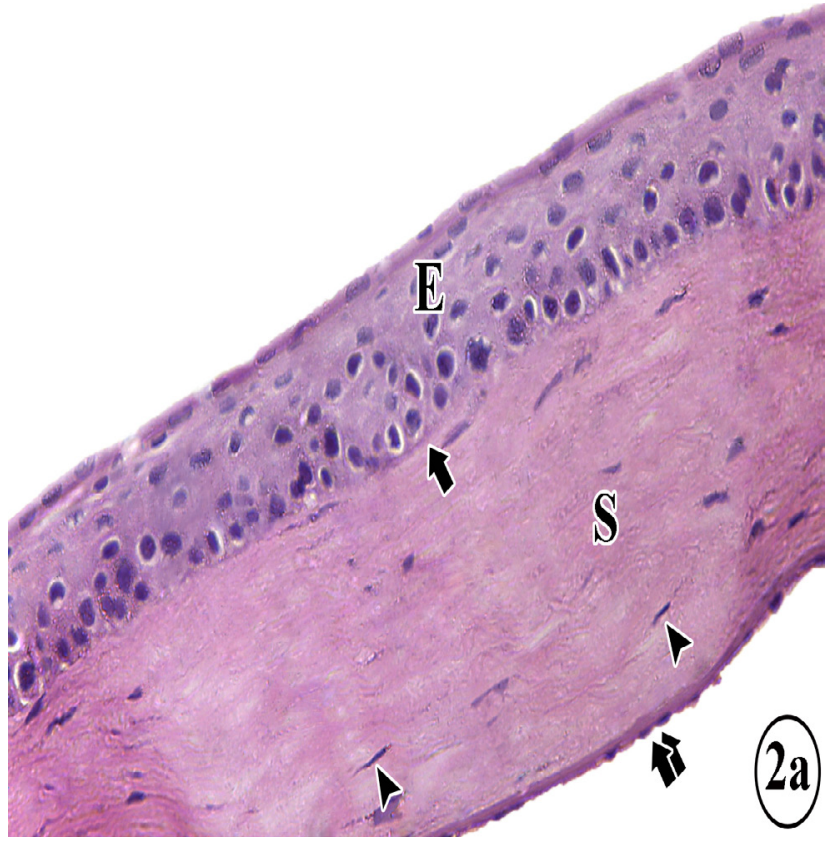

Fig. 2a: A photomicrograph of a rat corneal section of group I showing the corneal layers. The non-keratinized stratified squamous epithelium (E) rests on a regular basement membrane (arrow). The thick stroma (S) consists of regularly arranged collagen fibers and spindle shaped nuclei of keratocytes (arrow heads). The homogenous acidophilic Descemet's membrane is covered by Descemet's endothelium (double arrow).

(H\&E, X400).

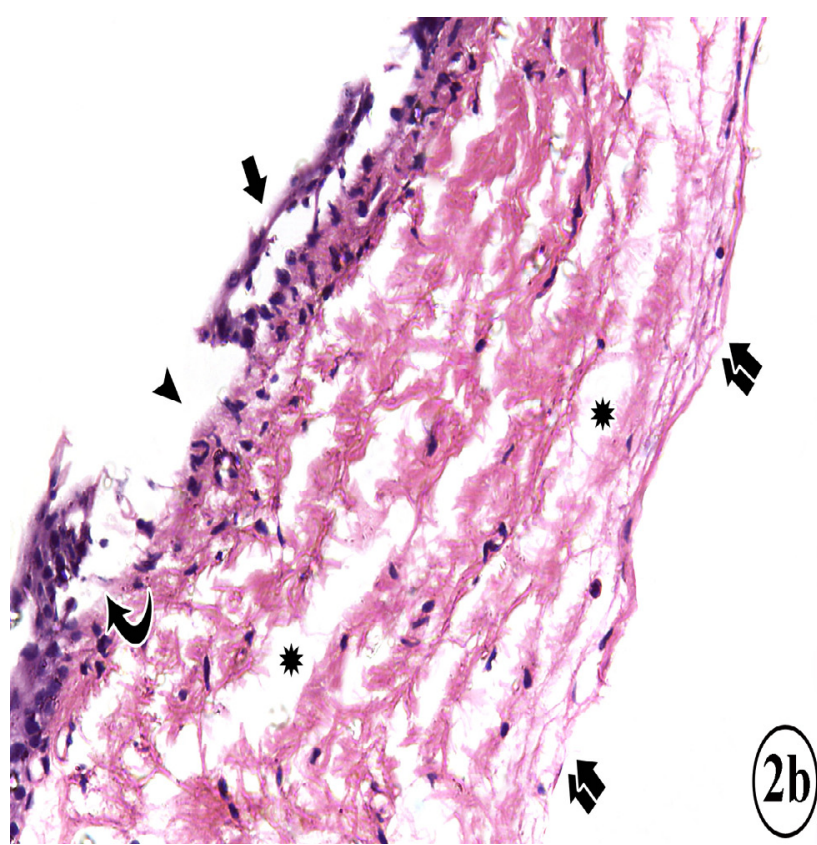

Fig. 2b: A photomicrograph of a rat corneal section of the group II showing separation of surface epithelial cells from the underlying epithelium (arrow). An area shows complete denudation of the epithelium with disrupted Bowman's membrane (arrow head) while another area showed separation of the epithelium from the underlying stroma (curved arrow). The stroma shows disorganized collagen fibers and wide spaces (asterisks). The Descemet's membrane and endothelium appear disrupted (double arrows).

$(\mathrm{H} \& \mathrm{E}, \times 400)$. 


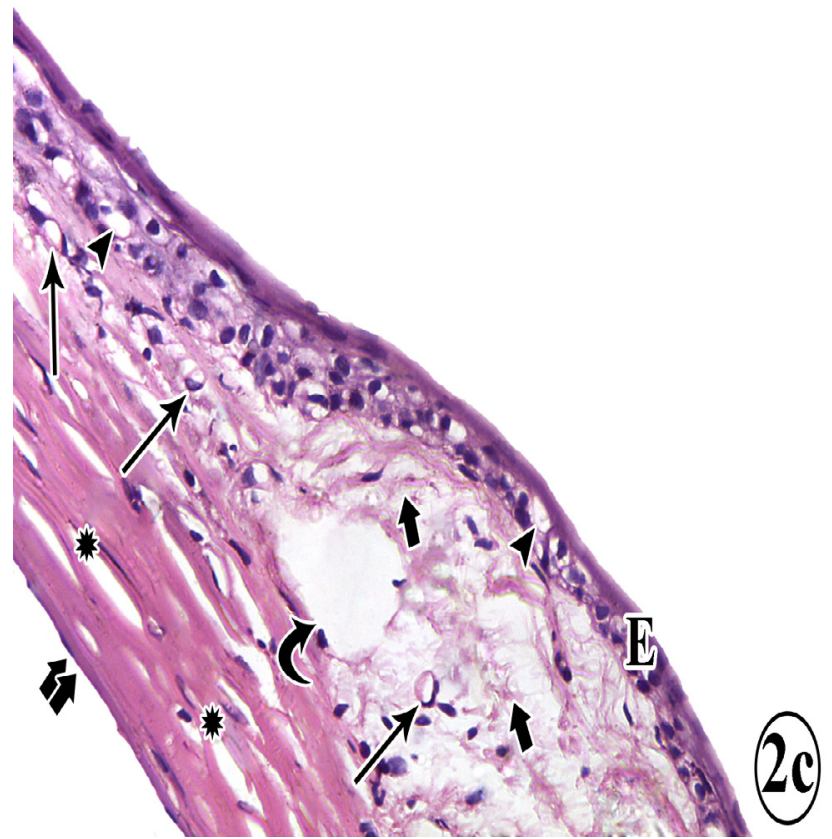

Fig. 2c: A photomicrograph of a rat corneal section of group III showing thinning of the corneal epithelium (E). Some epithelial cells show vacuolated cytoplasm (arrow heads). The upper part of the stroma consists of thin disorganized collagen fibers (arrows) and a wide space (curved arrow) while the lower part shows regularly arranged collagen fibers with numerous small spaces (asterisks). Nneovascularization (thin arrows) in the stroma is also observed. Descemet's membrane and endothelium appears continuous (double arrow).

$(\mathrm{H} \& \mathrm{E}, \times 400)$.

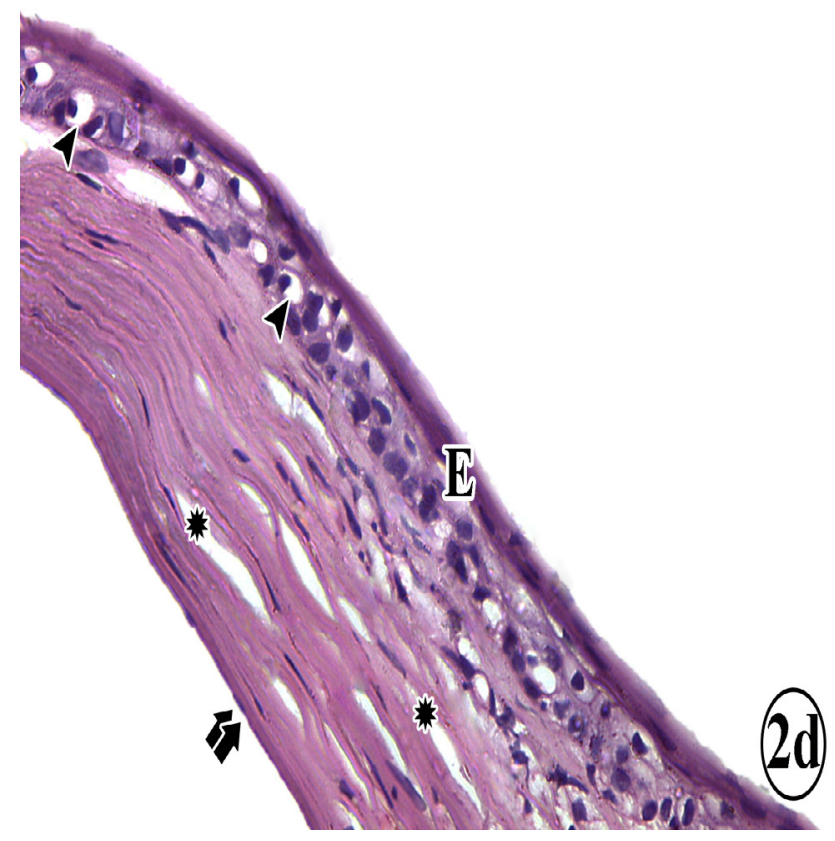

Fig. 2d: A photomicrograph of a rat corneal section of group IV showing thinning of the corneal epithelium (E). Some epithelial cells show vacuolated cytoplasm (arrow heads). Wide spaces between the collagen fibers of the stroma (asterisks). The Descemet's membrane appears acidophilic covered with Descemet's endothelium (double arrow).

$(\mathrm{H} \& \mathrm{E}, \times 400)$.

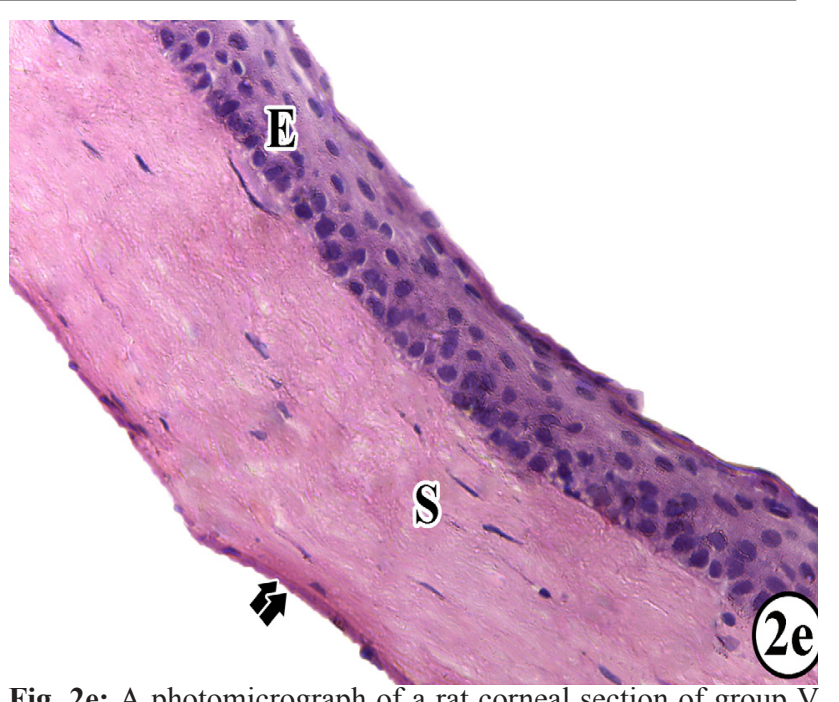

Fig. 2e: A photomicrograph of a rat corneal section of group $\mathrm{V}$ showing continuous corneal epithelium of uniform thickness. The stroma shows regular arranged collagen fibers and spindle shaped nuclei of keratocytes. The Descemet's membrane appears acidophilic and covered by Descemet's endothelium (double arrow). $\quad(\mathrm{H} \& \mathrm{E}, \times 400)$.
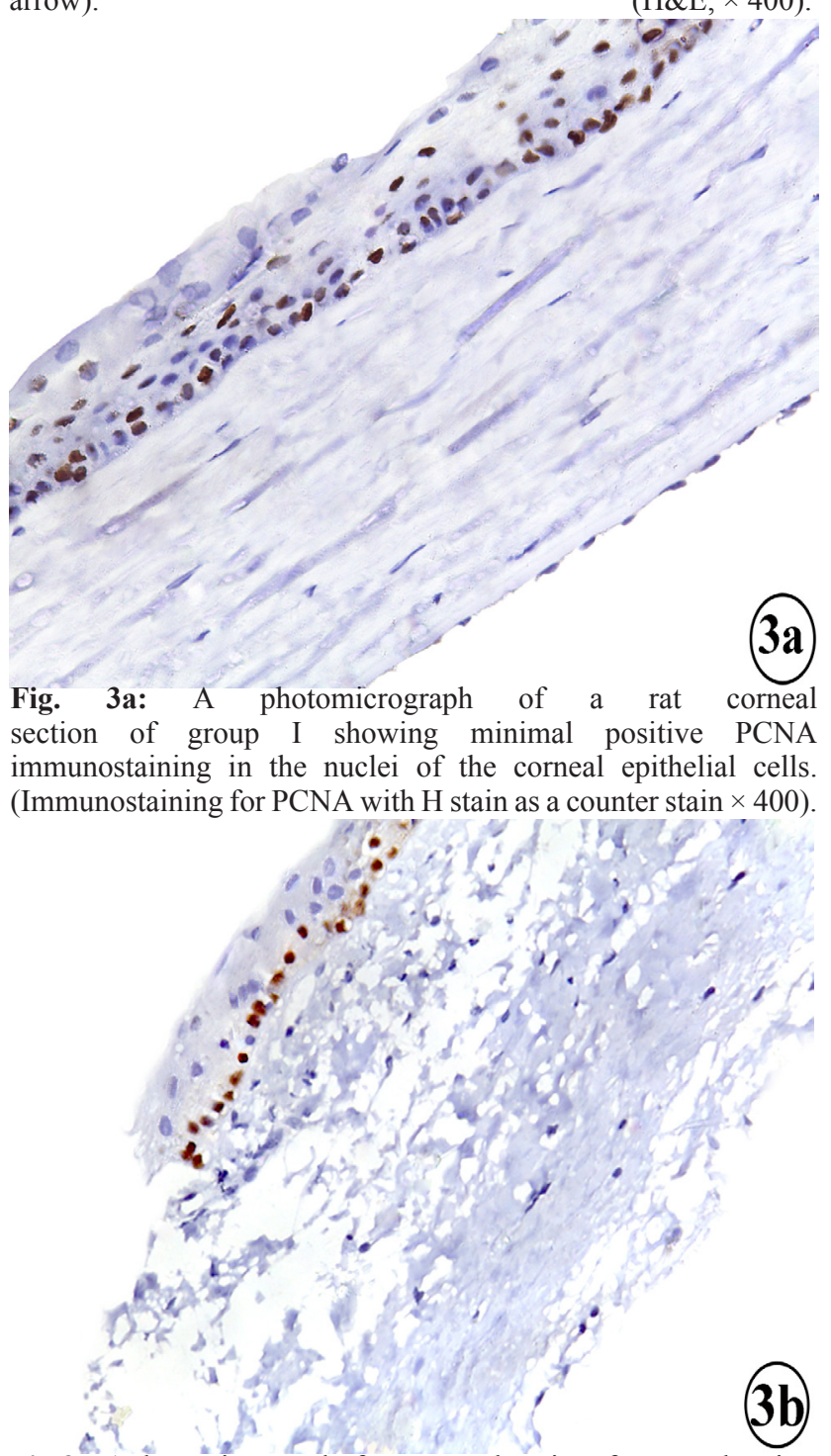

Fig.3b:AphotomicrographofaratcornealsectionofgroupIIshowing mild positive reaction in the nuclei of the corneal epithelial cells. (Immunostaining for PCNA with $\mathrm{H}$ stain as a counter stain $\times$ 400). 


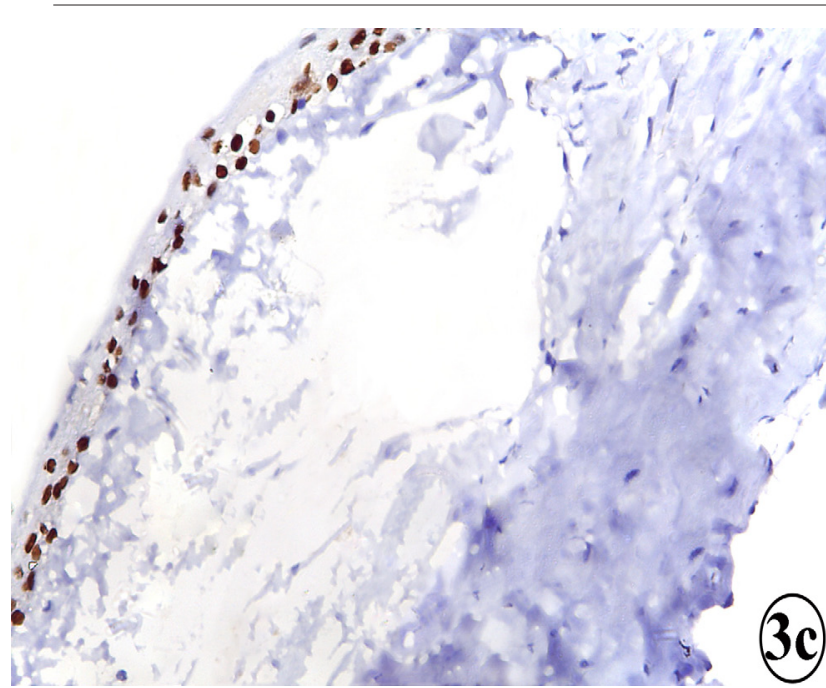

Fig. 3c: A photomicrograph of a rat corneal section of group III showing moderate positive reaction in the nuclei of corneal epithelial cells. (Immunostaining for PCNA with $\mathrm{H}$ stain as a counter stain $\times 400$ ).

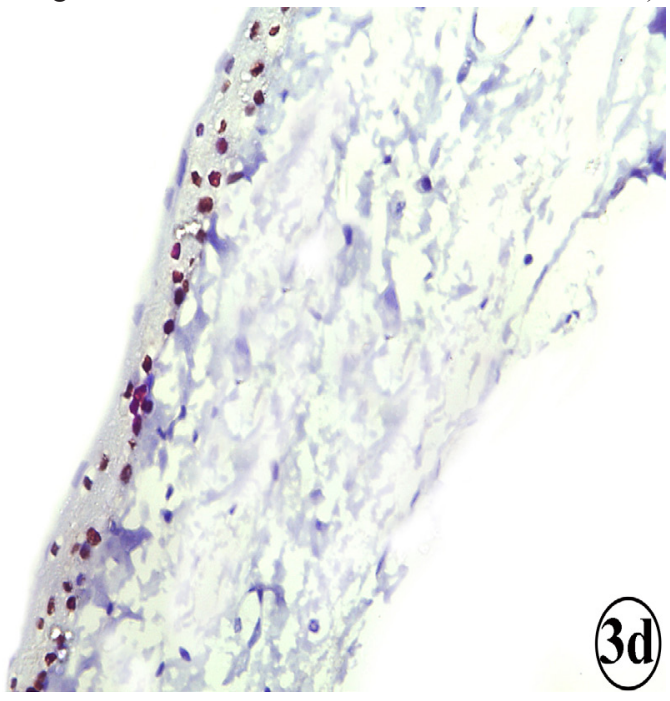

Fig. 3d: A photomicrograph of a rat corneal section of group IV showing highly positive PCNA immunostaining in the nuclei of the corneal epithelial cells. (Immunostaining for PCNA and $\mathrm{H}$ stain as a counter stain $\times 400$ ).

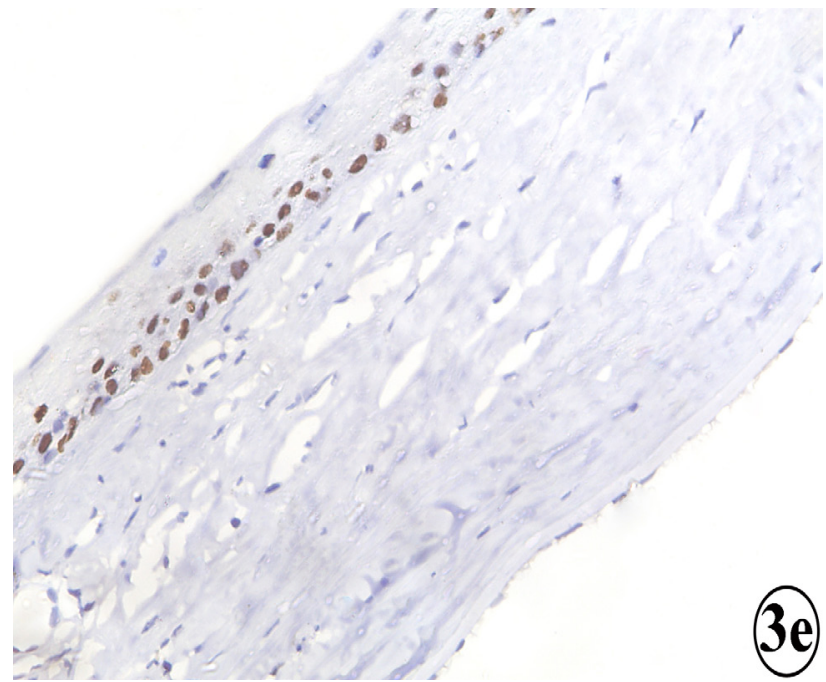

Fig. 3e: A photomicrograph of a rat corneal section of group $\mathrm{V}$ showing intense positive PCNA immunostaining in the nuclei of the corneal epithelial cells. (Immunostaining for PCNA and $\mathrm{H}$ stain as a counter stain $\times 400$ ).

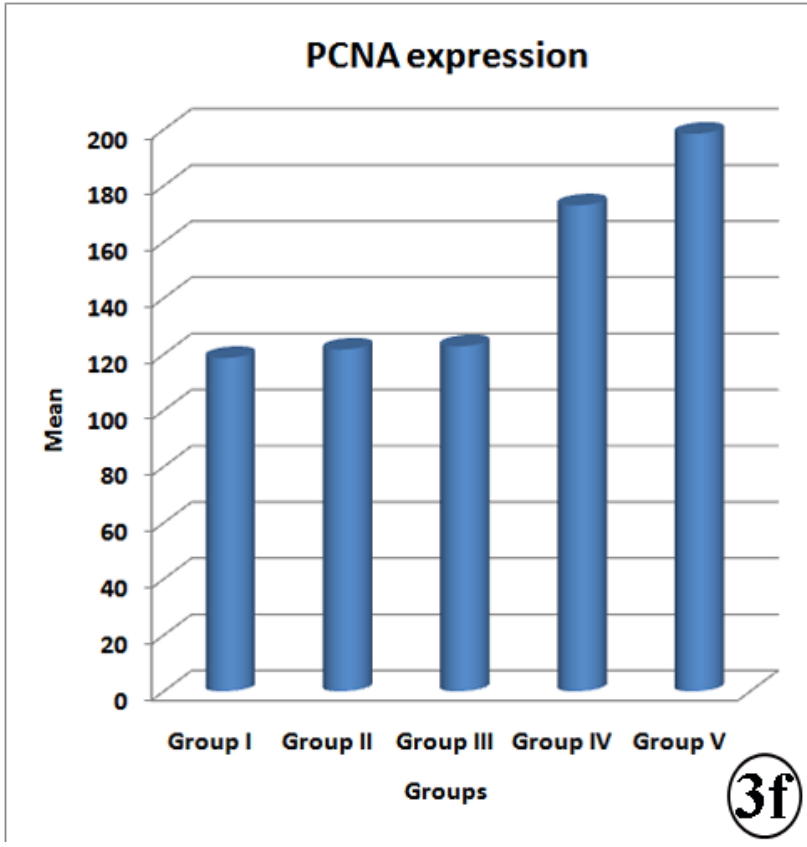

Fig.3f: A bar chart showing the mean of PCNA expression for all groups.

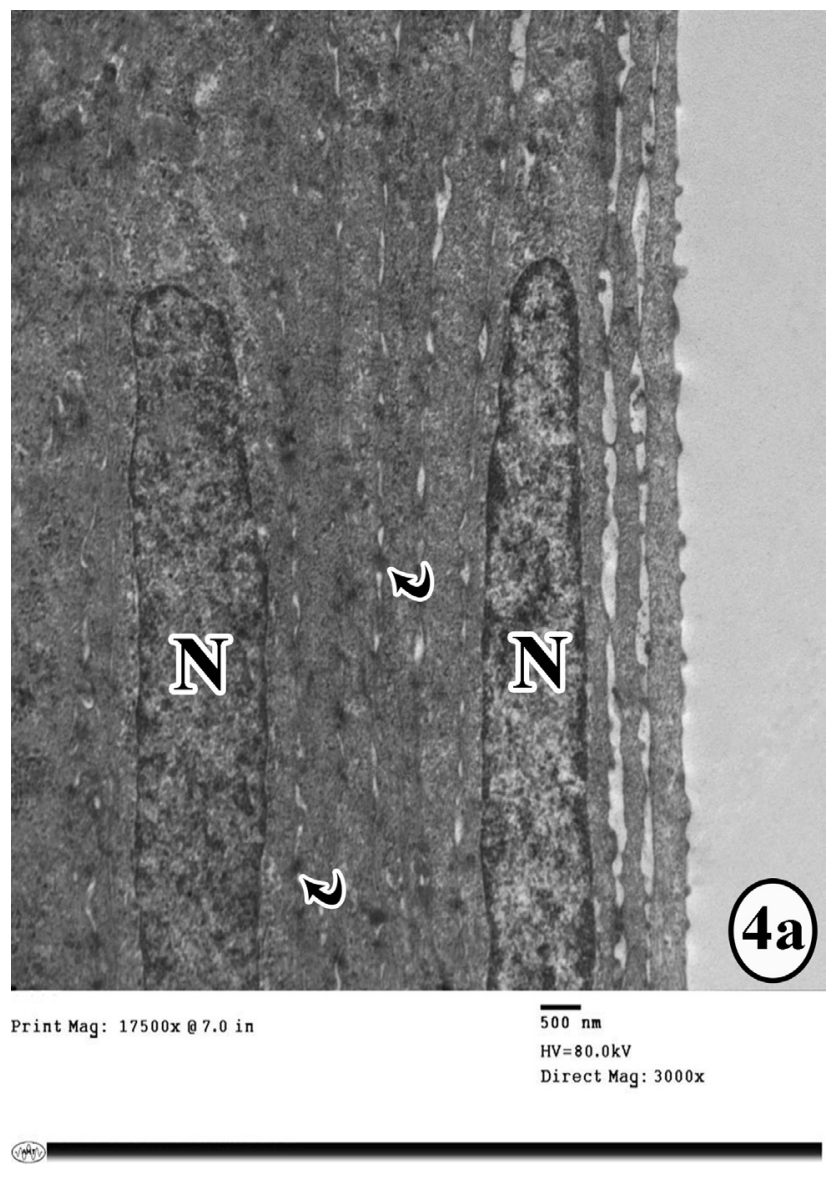

Fig. 4a: An electron micrograph of a rat cornea of group I showing the squamous cells of the superficial layer. Their nuclei appear flattened and euchromatic $(\mathrm{N})$. The cells are connected by desmosomes (curved arrows).

(TEM, X3000). 


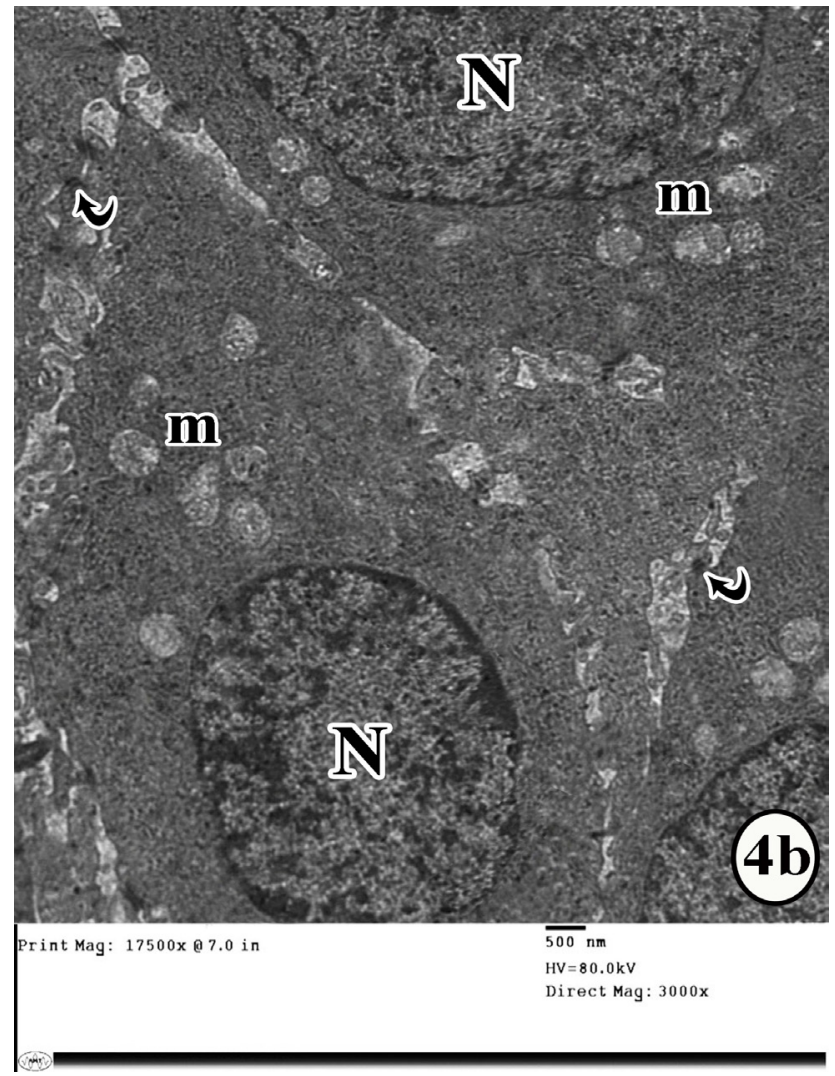

Fig. 4b: An electron micrograph of a rat cornea of group I showing polygonal cells of the intermediate layer with rounded euchromatic nuclei $(\mathrm{N})$. The cytoplasm contains numerous mitochondria (m). Adjacent cell are connected by desmosomes (curved arrows).

(TEM, X3000).

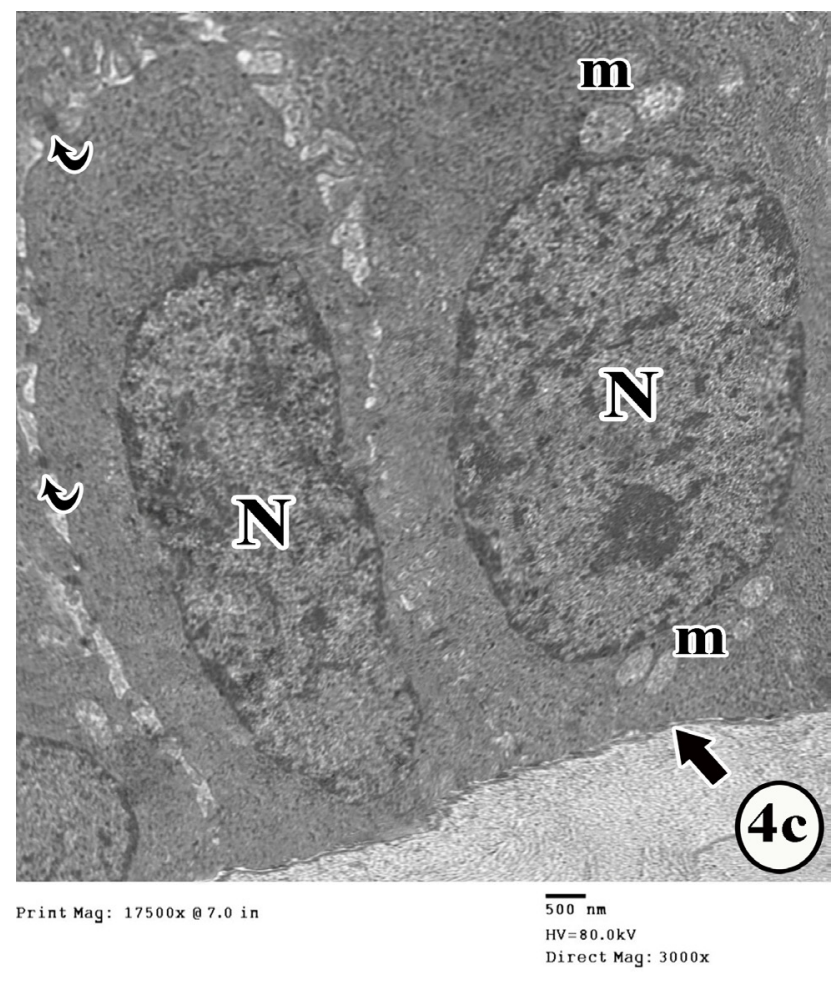

Fig. 4c: An electron micrograph of a rat cornea of group I showing columnar cells of the basal layer with euchromatic nuclei $(\mathrm{N})$ resting on a regular basement membrane (arrow). The cytoplasm contains mitochondria (m). Desmosomes (curved arrows) connecting the cells.

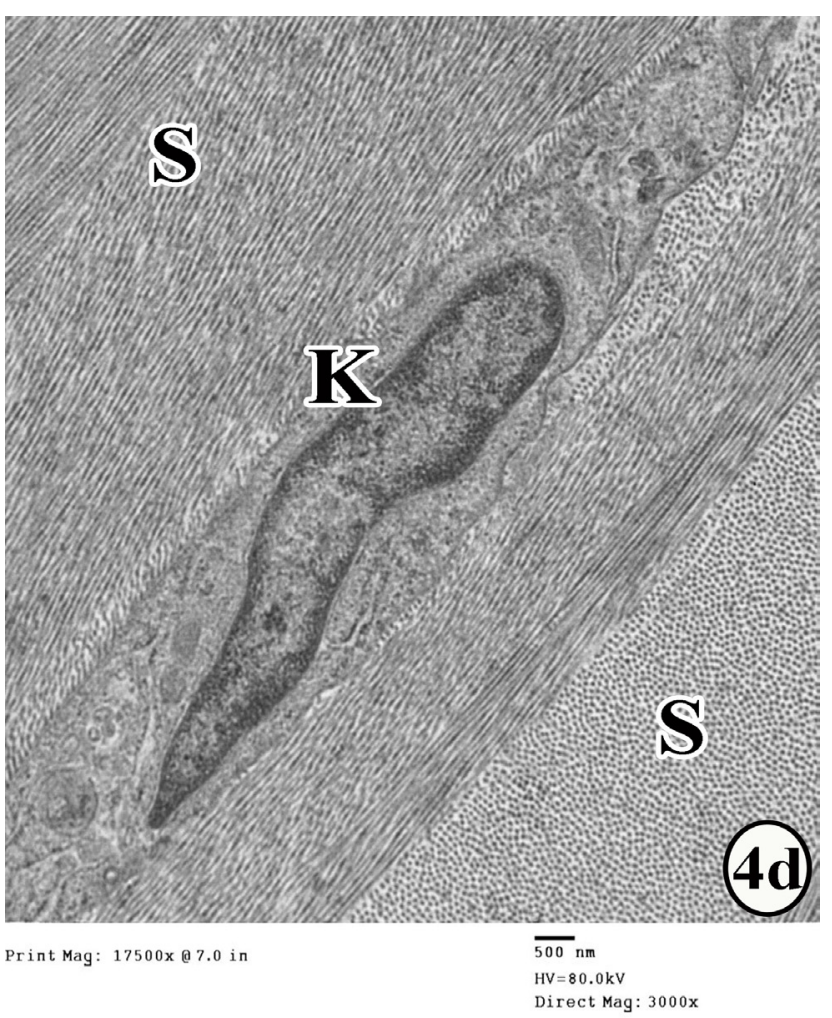

Fig. 4d: An electron micrograph of a rat cornea of group I showing regular orthogonal arrangement of the collagen fibrils of the stroma $(\mathrm{S})$. A keratocyte $(\mathrm{K})$ appears spindle shaped with a euchromatic nucleus $(\mathrm{N})$ and cytoplasmic organelles.

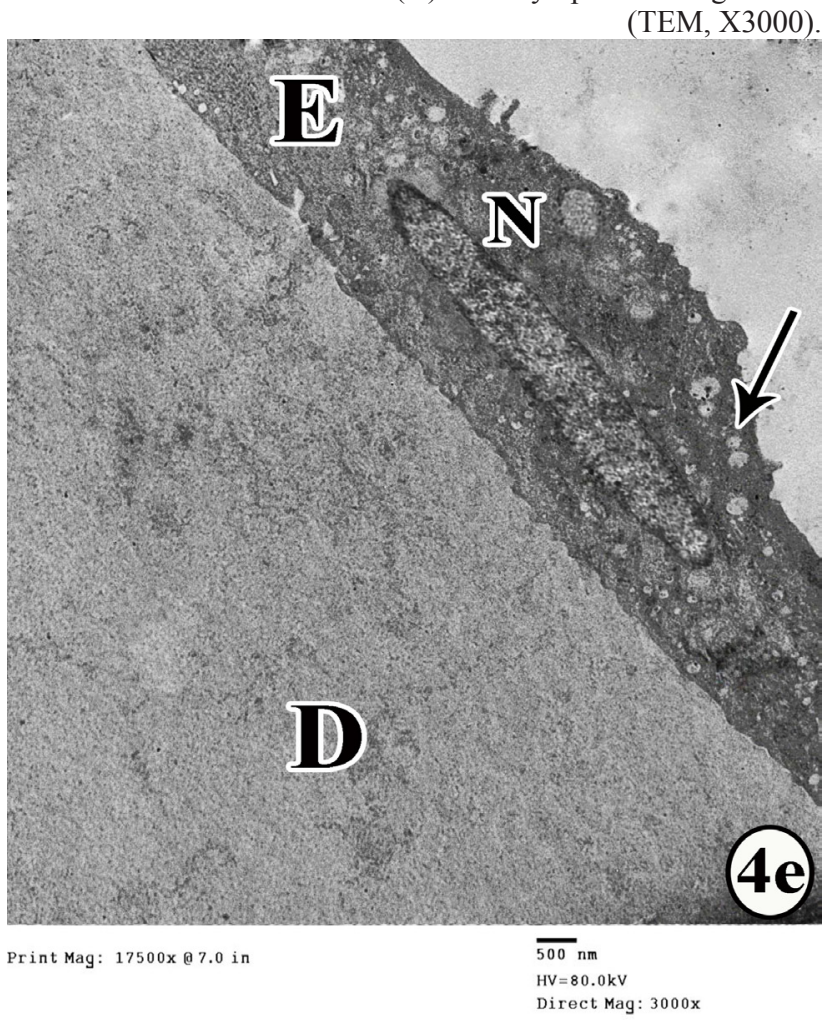

Fig. 4e: An electron micrograph of a rat cornea of group I showing homogenous Descemet's membrane (D). The endothelial cell (E) shows a flattened euchromatic nucleus $(\mathrm{N})$ and the cytoplasm contains variable sized pinocytotic vesicles (thin arrow). (TEM, X 3000) 


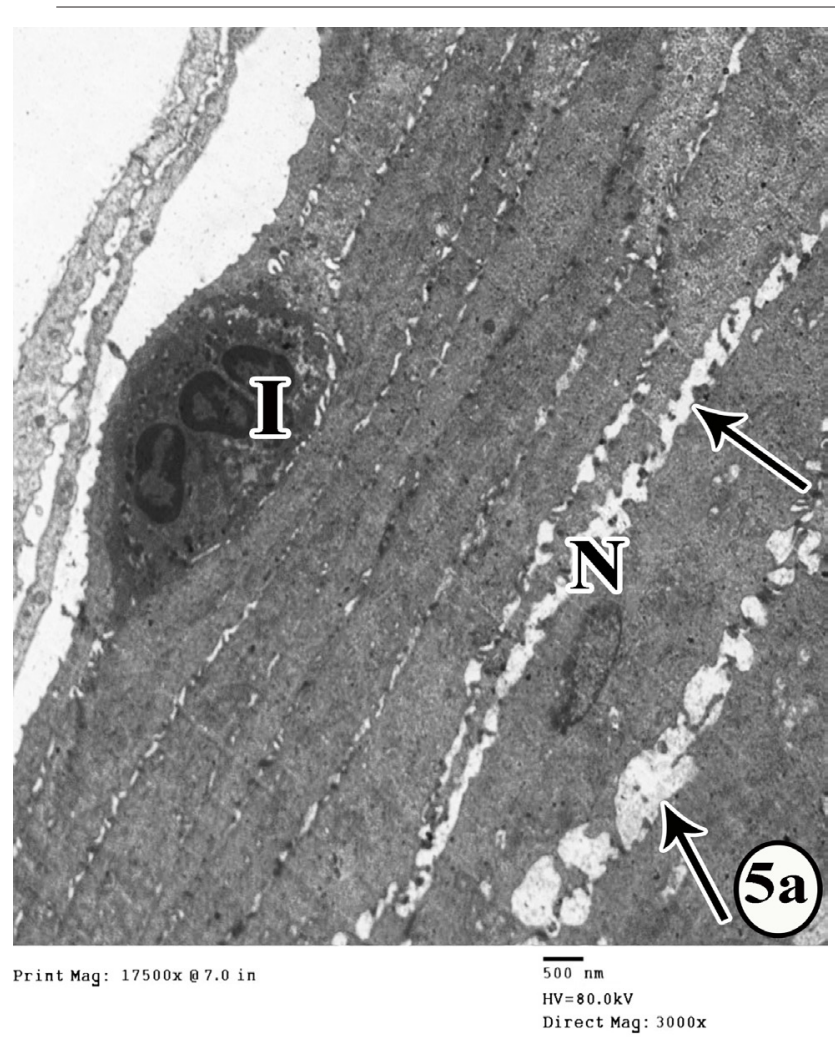

Fig. 5a: An electron micrograph of a rat cornea of group II showing the squamous cells of the superficial layer separated by wide intercellular spaces (thin arrows). A nucleus (N) appears shrunken. An inflammatory cell could be seen (I). (TEM, X3000).

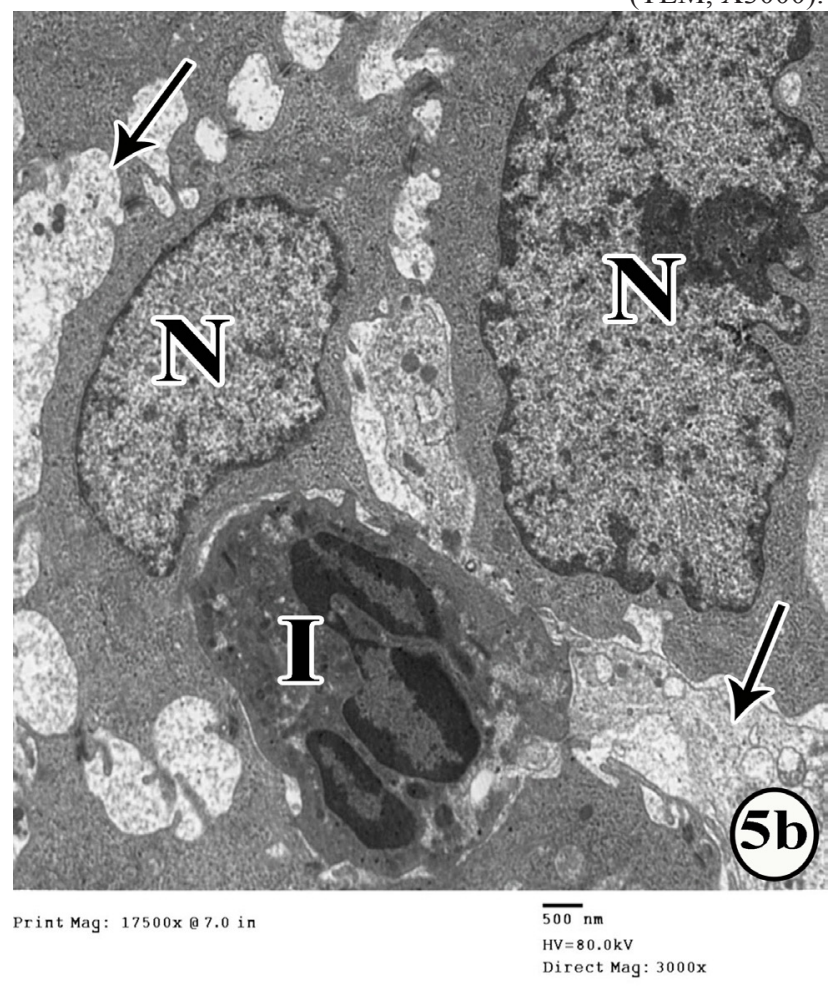

Fig. 5b: An electron micrograph of a rat cornea of group II showing cells of the intermediate layer with irregular shape and nuclei $(\mathrm{N})$. The cells are separated by wide intercellular spaces (thin arrows) and an inflammatory cell (I) could be seen (TEM, X3000).

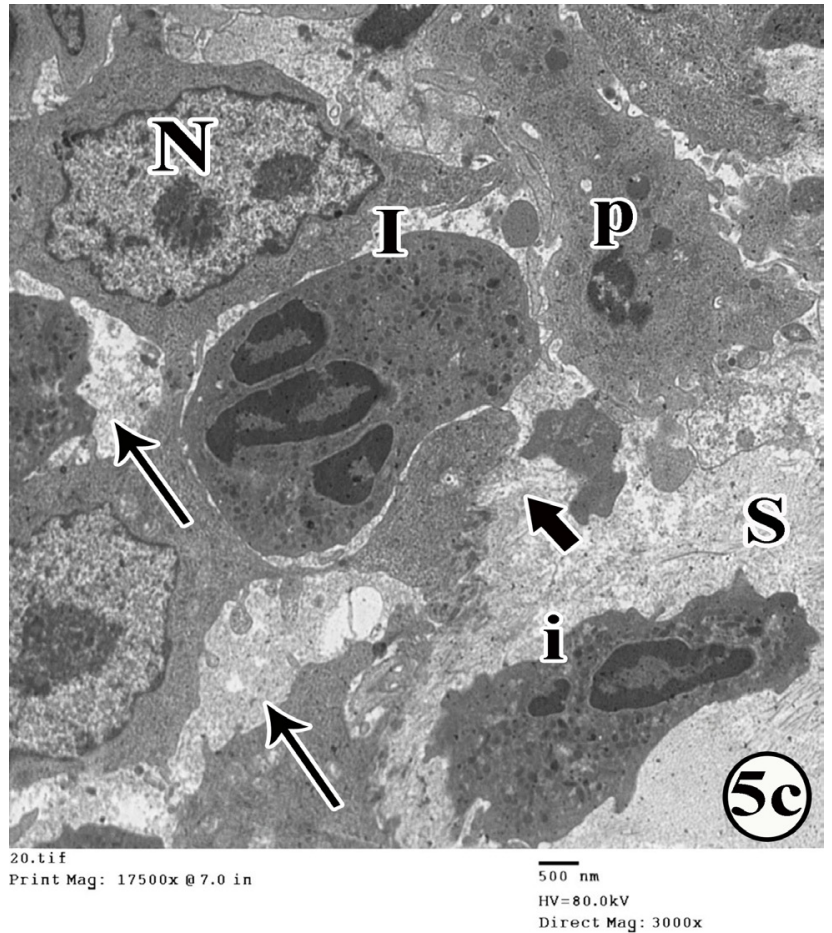

Fig. 5c: An electron micrograph of a rat cornea of group II showing irregular shaped cells of the basal layer separated by wide intercellular spaces (thin arrows) and inflammatory cells (I). Some epithelial cells possess irregular nuclei $(\mathrm{N})$ while others have shrunken heterochromatic nuclei (p). The basement membrane appears interrupted (arrow) while an inflammatory cell (i) can be seen in the stroma (S) (TEM, X3000)

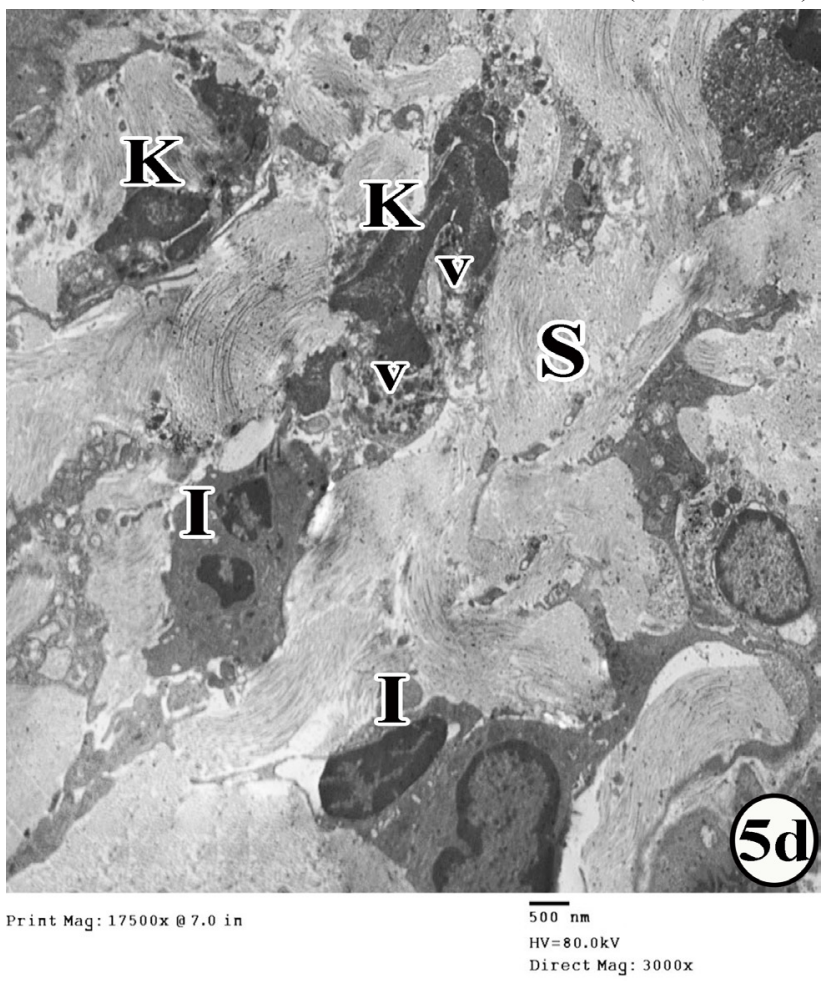

Fig. 5d: An electron micrograph of a rat cornea of group II showing disorganized collagen fibrils of the stroma (S) and inflammatory cells (I). Keratocytes $(\mathrm{K})$ show irregular heterochromatic nuclei and vacuolated cytoplasm (v).

(TEM, X3000). 


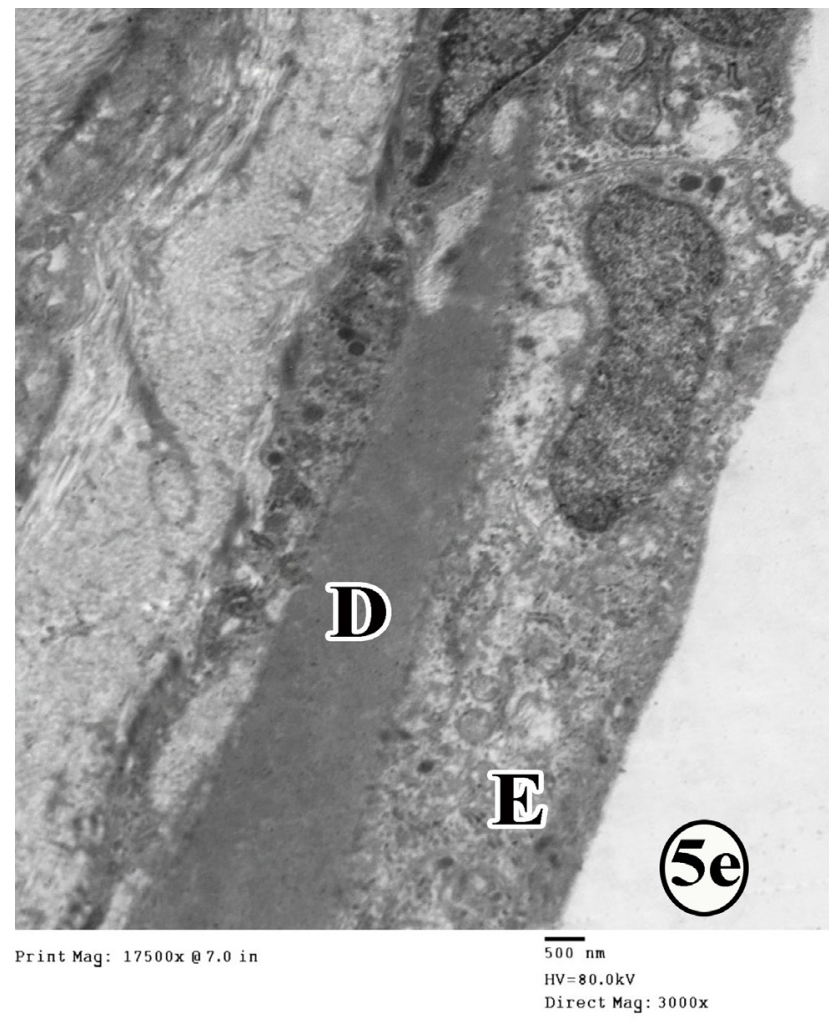

Fig. 5e: An electron micrograph of a rat cornea of group II showing attenuated and interrupted Descemet's membrane (D). The endothelial cell (E) shows a rarified cytoplasm and nucleus.

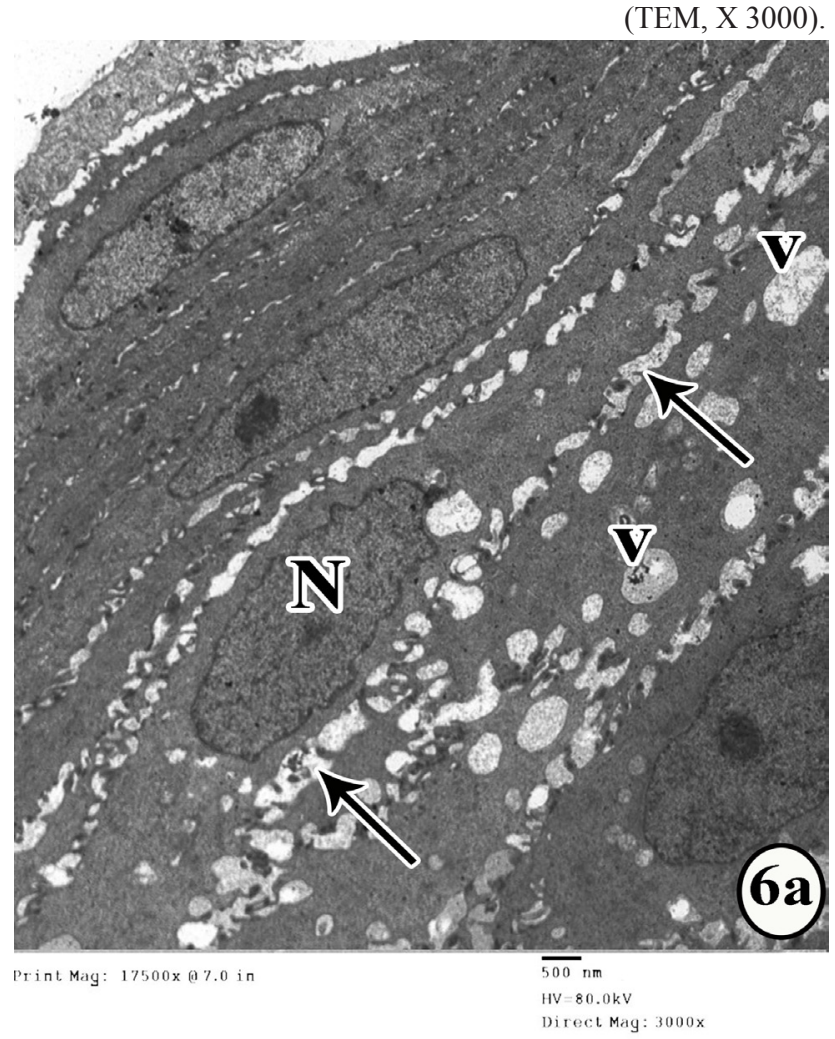

Fig 6a: An electron micrograph of a rat cornea of group III showing the superficial squamous epithelial cells separated by wide intercellular spaces (thin arrows). The nuclei have irregular contours $(\mathrm{N})$ and the cytoplasm contains multiple vacuoles $(\mathrm{v})$ (TEM, X3000).

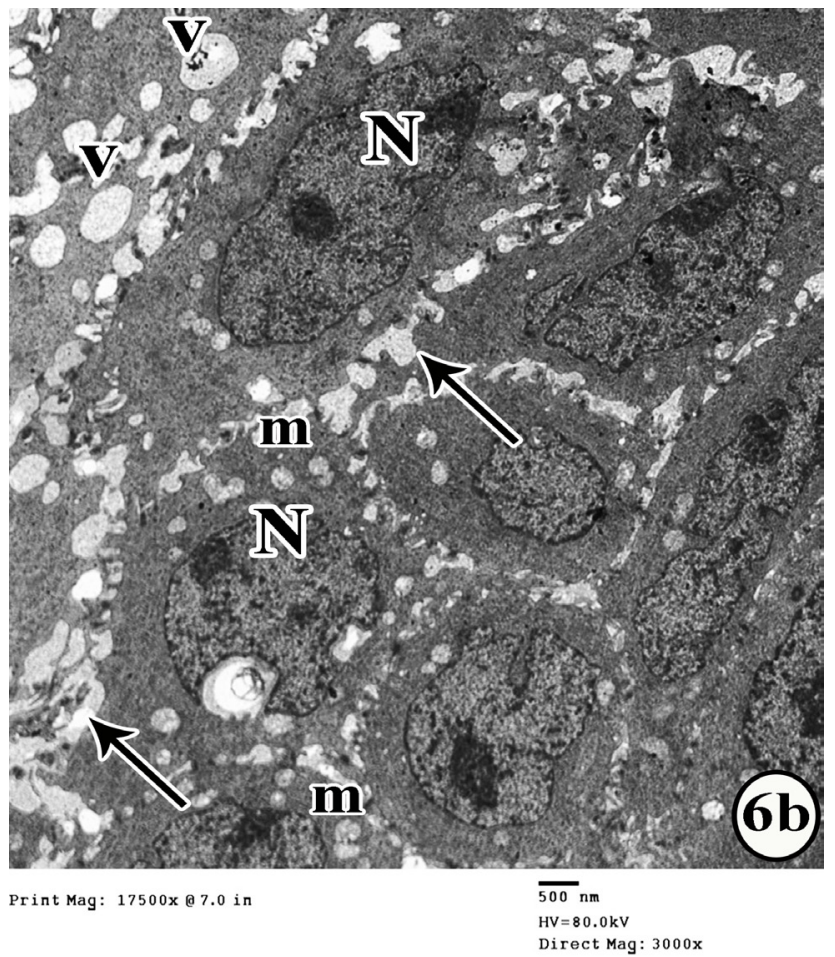

Fig 6b: An electron micrograph of a rat cornea of group III showing cells of the intermediate layer separated by wide intercellular spaces (thin arrows). The nuclei have irregular contours $(\mathrm{N})$ and the cytoplasm contains multiple vacuoles (v) and mitochondria with disrupted cristae $(\mathrm{m})$.

(TEM, x3000)

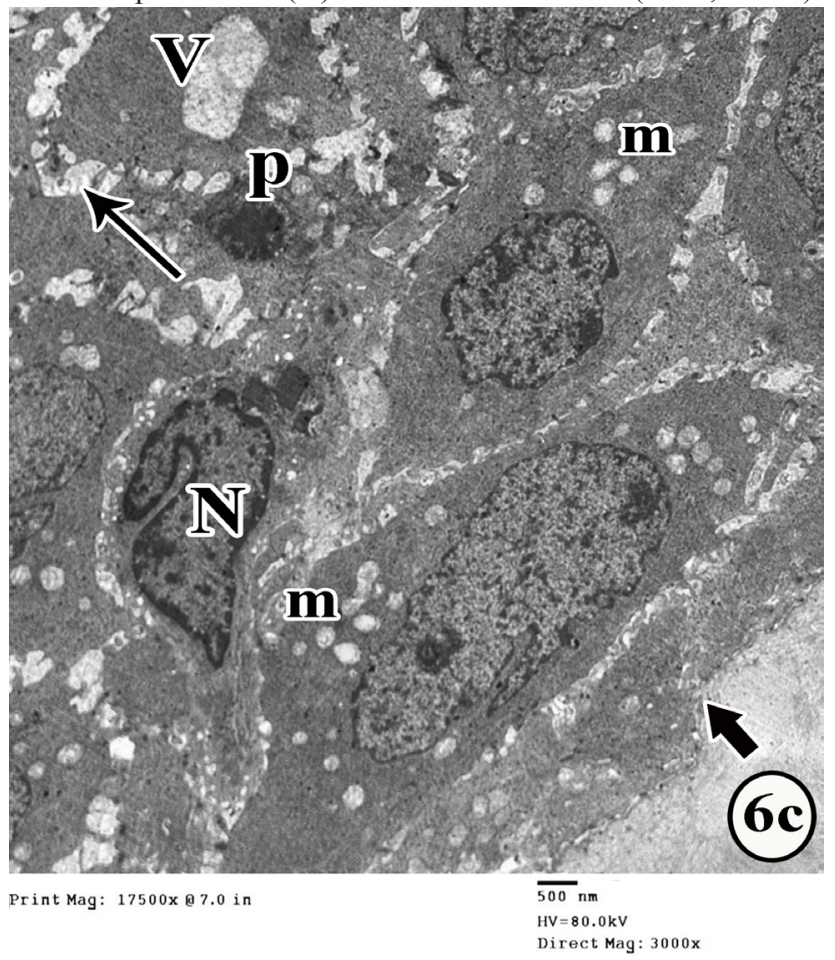

Fig. 6c: An electron micrograph of a rat cornea of group II showing cells of the basal layer separated by wide intercellular spaces (thin arrows) resting on an irregular basement membrane (arrow). Some cells possess irregular nuclei $(\mathrm{N})$ while others have shrunken heterochromatic nuclei (p). The cytoplasm contains vacuoles (v) and mitochondria with disrupted cristae (m).

(TEM, X3000). 


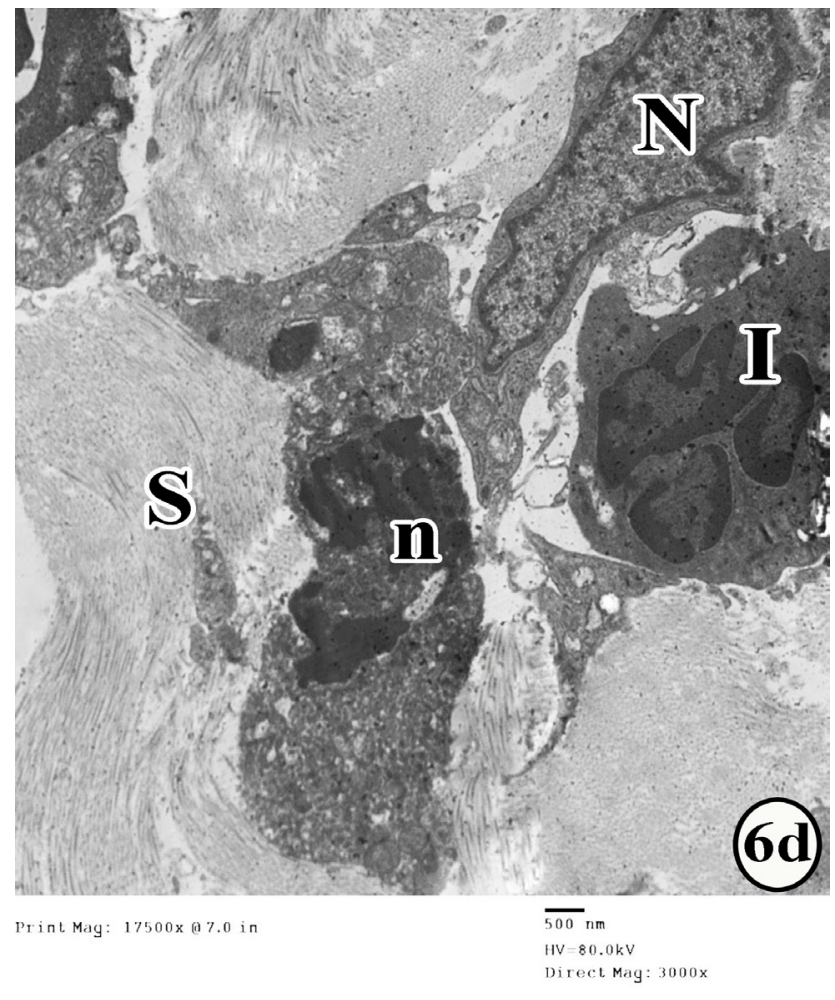

Fig. 6d: An electron micrograph of a rat cornea of group III showing the upper part of the stroma (S) with disorganized collagen fibrils and inflammatory cells (I). A keratocyte possesses an irregular euchromatic nucleus $(\mathrm{N})$ while the other shows irregular heterochromatic nucleus (n). (TEM, X3000)

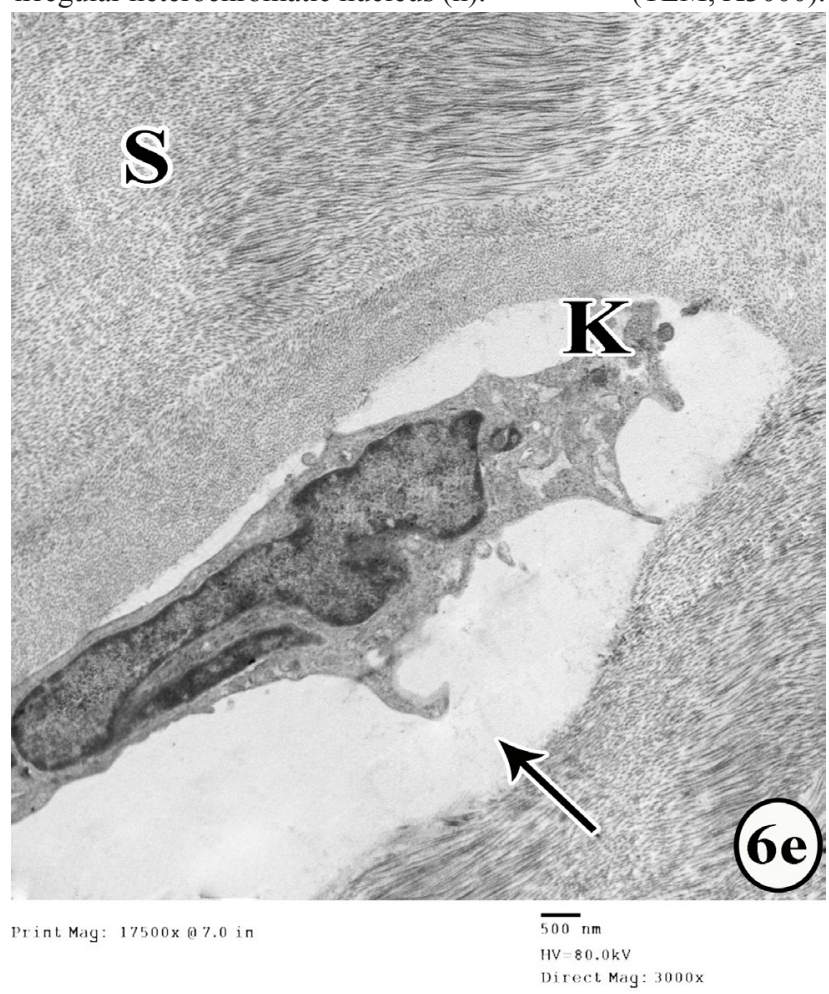

Fig. 6e: An electron micrograph of a rat cornea of group III showing the lower part of the stroma (S) with regular arrangement of collagen fibrils. A keratocyte $(\mathrm{K})$ possesses an irregular contour and nucleus is surrounded by an area devoid of collagen fibrils (thin arrow).

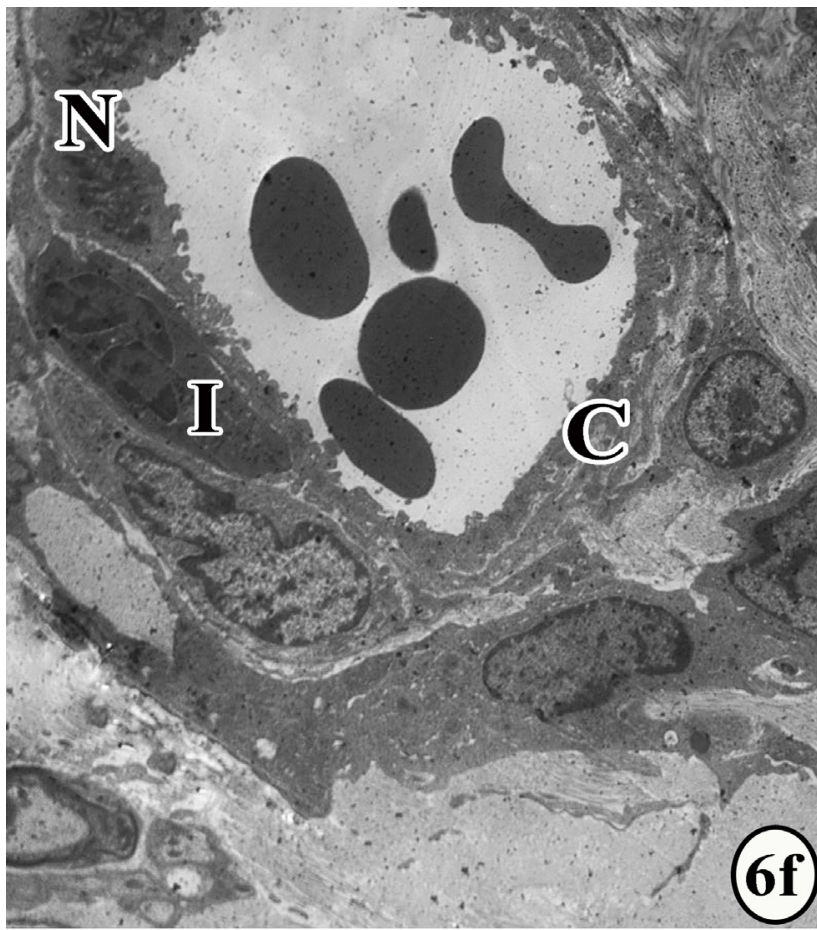

$\overline{500} \mathrm{~nm}$

$\mathrm{HV}=80.0 \mathrm{kV}$
Direct Mag: $3000 \mathrm{x}$

Fig. 6f: An electron micrograph of a rat cornea of group III showing a dilated blood vessel (C) in the stroma with heterochromatic nuclei $(\mathrm{N})$ of endothelial cells. An inflammatory cell (I) is seen near the blood vessel.

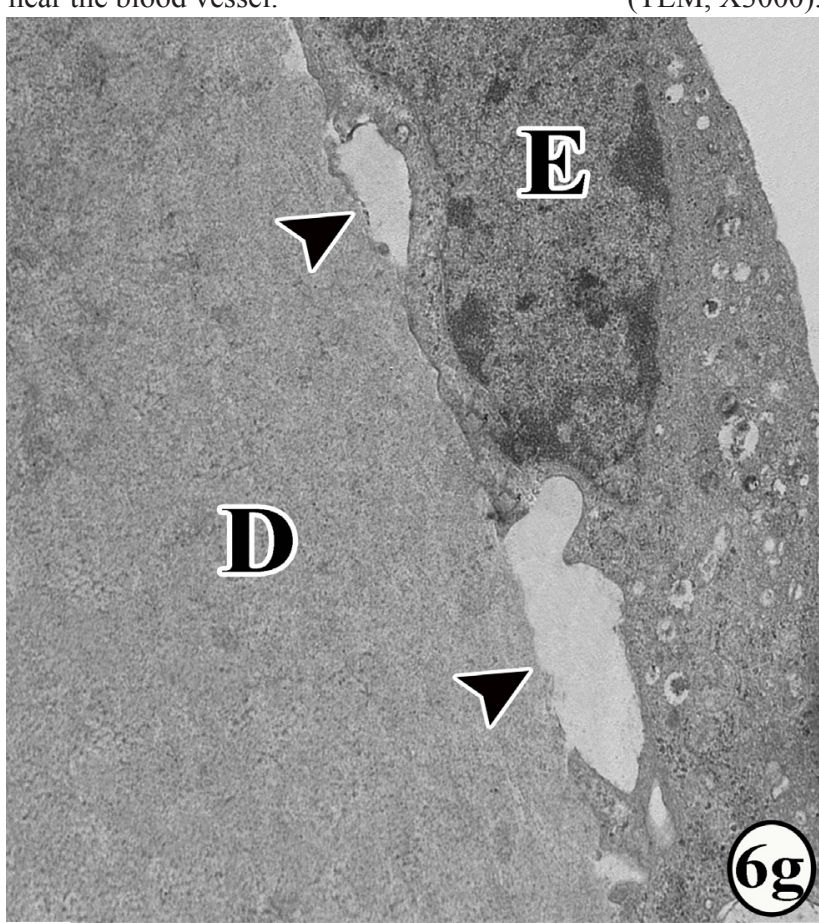

Print Mag: $17500 \times$ [ 7.0 in

$\overline{500} \mathrm{~nm}$

$\mathrm{HV}=80.0 \mathrm{kV}$

Fig. 6g: An electron micrograph of a cornea of a rat of group III Fig. 6g: An electron micrograph of a cornea of a rat of group
showing homogenous Descemet's membrane (D) and separation of the endothelial cell (E) from the underlying Descemet's membrane (arrow heads). 


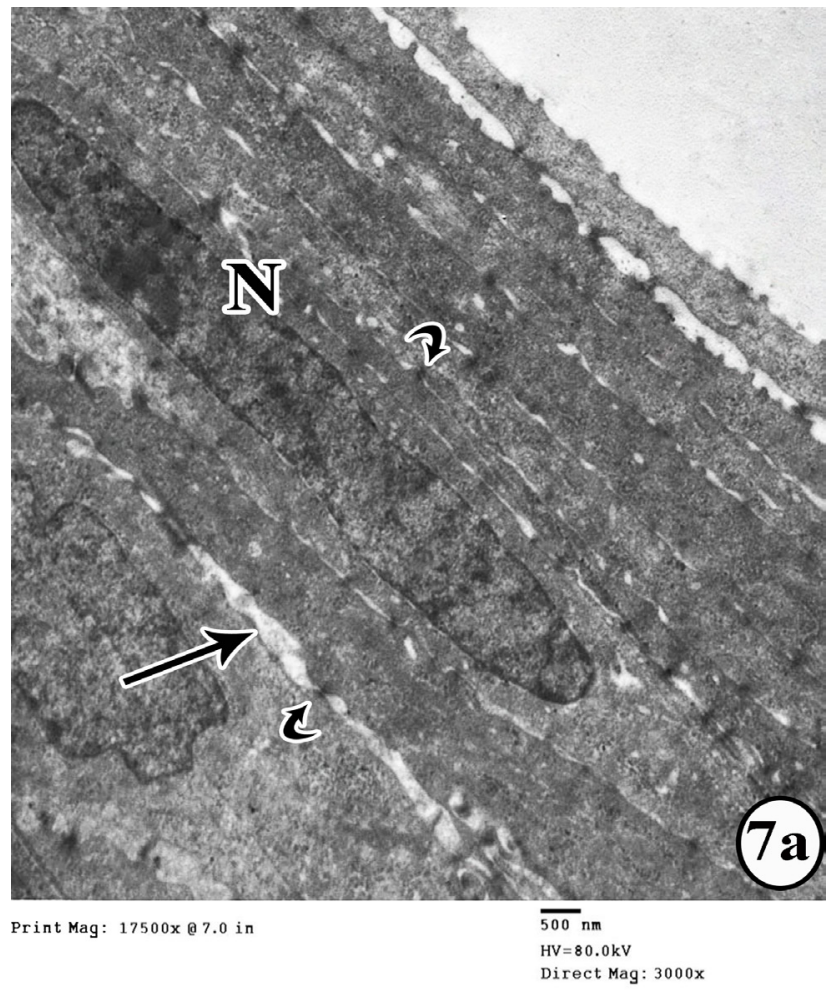

Fig. 7a: An electron micrograph of a rat cornea of group IV showing superficial squamous cells with euchromatic nuclei $(\mathrm{N})$. Notice the presence of minimal intercellular spaces (thin arrow) and desmosomes (curved arrows) connecting the cells to each other.

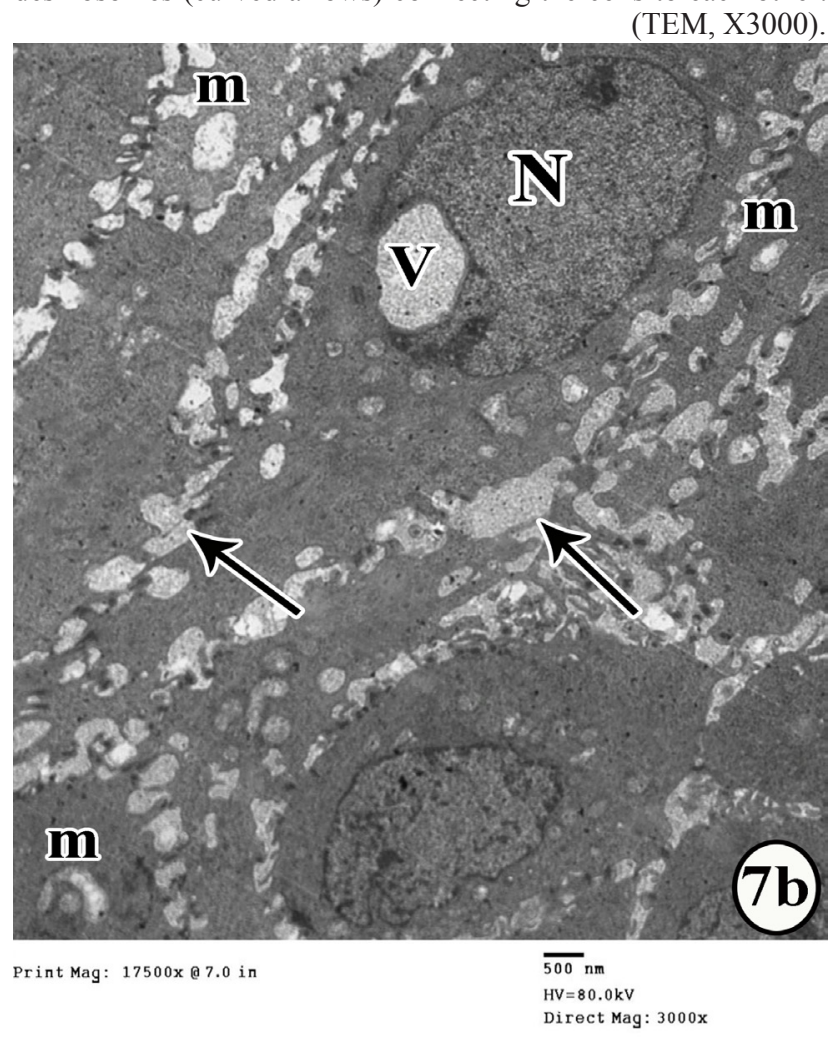

Fig. 7b: An electron micrograph of a rat cornea of group IV showing irregular shaped cells of the intermediate layer separated by wide intercellular spaces (thin arrows). A nucleus $(\mathrm{N})$ appears indented by a vacuole $(\mathrm{V})$. The cytoplasm contains numerous mitochondria with disrupted cristae (m).

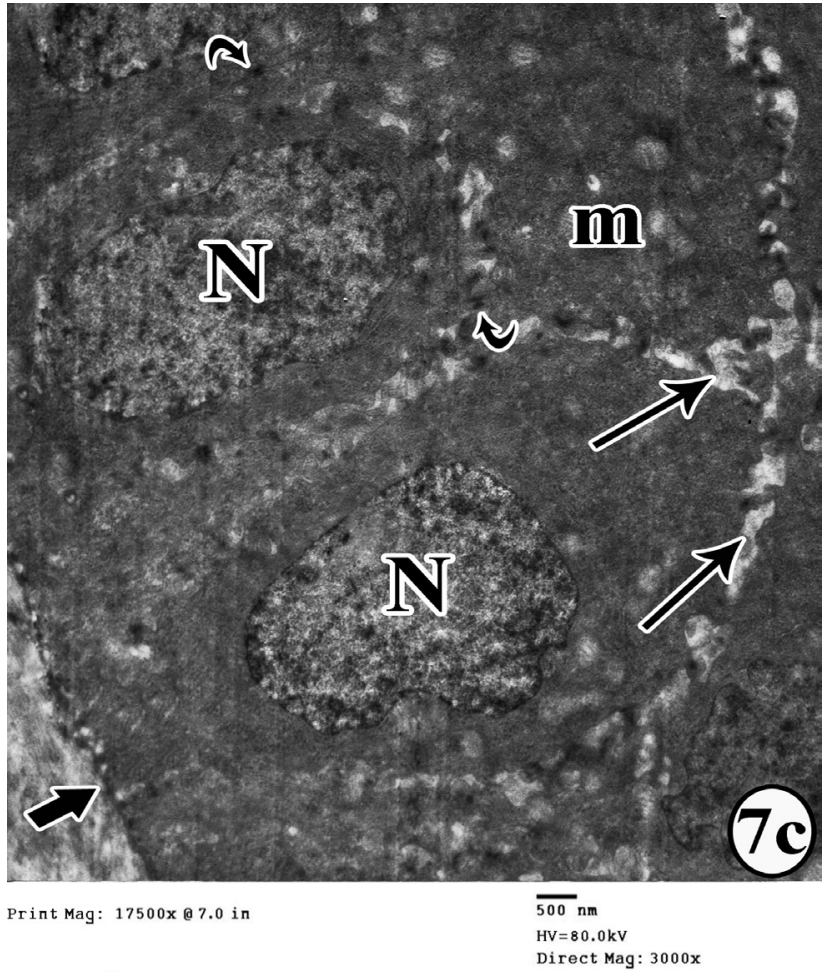

Fig. 7c: An electron micrograph of a rat cornea of group IV showing cells of the basal layer resting on a regular basement membrane (arrow). The cells are connected by desmosomes (curved arrows) with minimal intercellular spaces (thin arrows). The nuclei $(\mathrm{N})$ appear irregular and euchromatic and the cytoplasm contains numerous mitochondria $(\mathrm{m})$. (TEM, X3000).

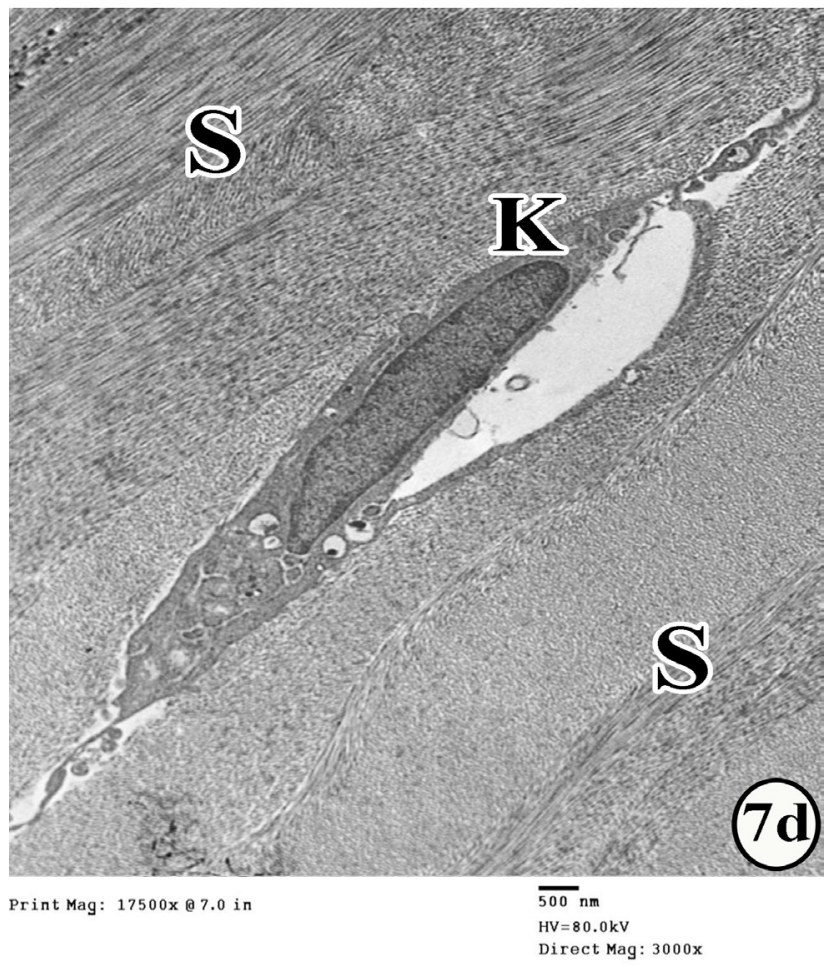

Fig 7d: An electron micrograph of a rat cornea of group IV showing the stroma (S) with regular orthogonal arrangement of the collagen fibrils. The keratocyte $(\mathrm{K})$ shows aneuchromatic nucleus and a large vacuole. 


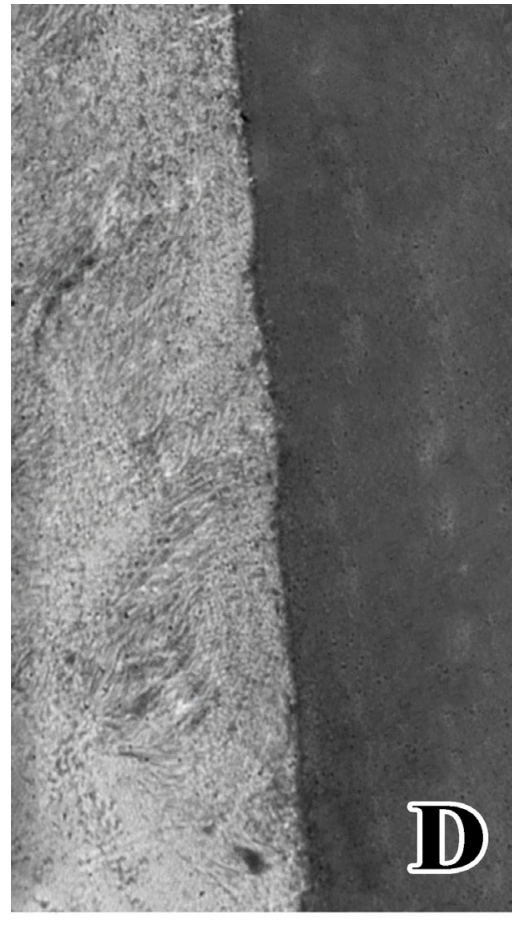

Print Mag: $17500 \mathrm{x}$ ( $7.0 \mathrm{in}$
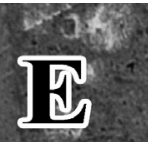

$\mathbb{N}$

Fig. 7e: An electron micrograph of a rat cornea of group IV showing thinning of Descemet's membrane (D). The endothelial cell (E) appears attenuated with part of a flattened nucleus (N) and cytoplasm containing mitochondria with disrupted cristae $(\mathrm{m})$.

(TEM, X 3000)

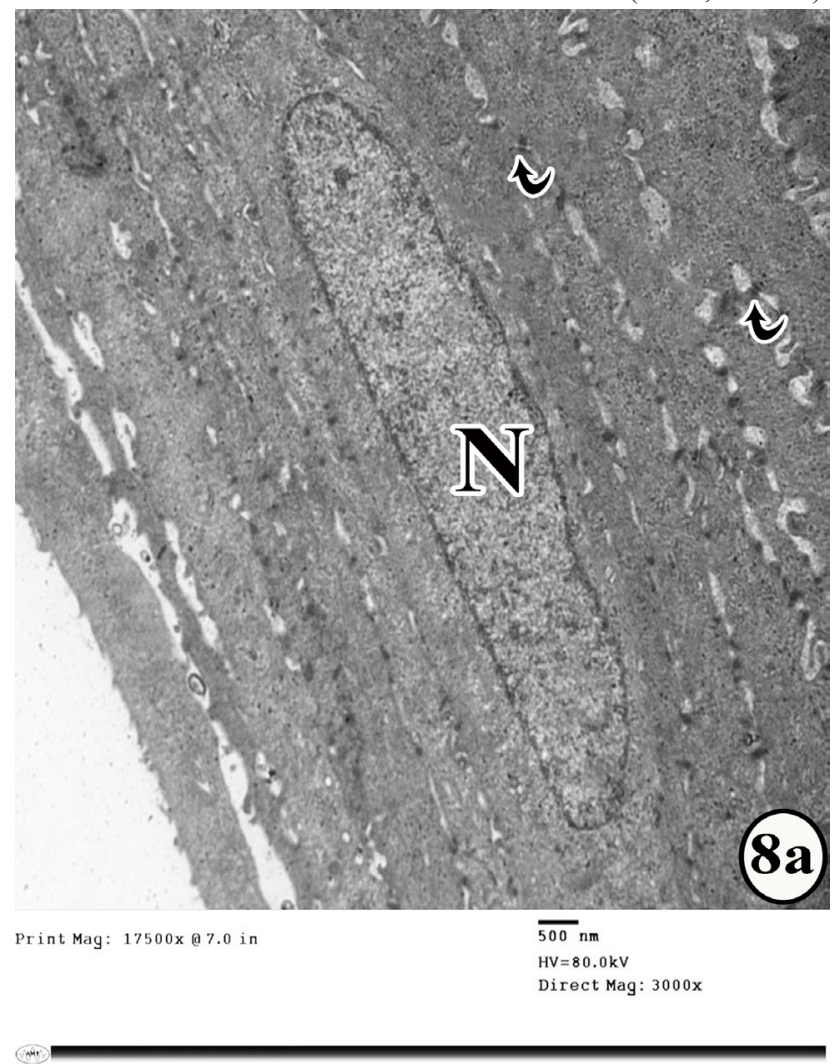

Fig. 8a: An electron micrograph of a rat cornea of group $\mathrm{V}$ showing the squamous cells of the superficial layer with a flattened euchromatic nucleus (N). Desmosomes (curved arrows) are seen connecting the cells.

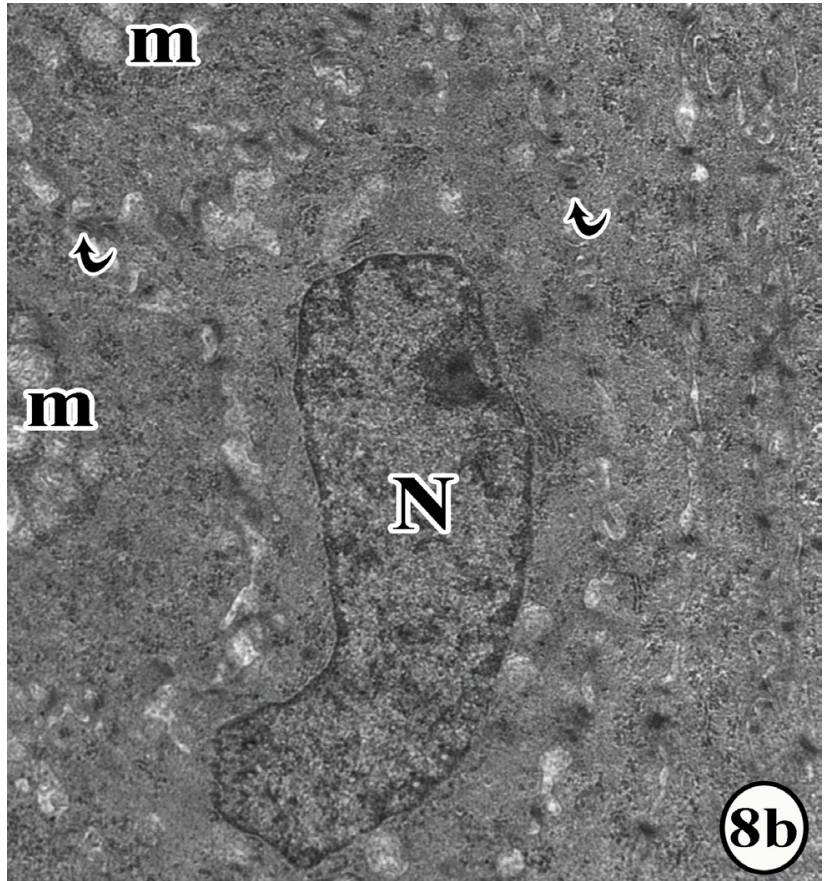

Print Mag: $17500 x$ e 7.0 in

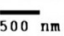

$\mathrm{HV}=80.0 \mathrm{kV}$ Direct Mag: $3000 \mathrm{x}$

Fig. 8b: An electron micrograph of a rat cornea of group $V$ showing cells of the intermediate layer with euchromatic nuclei (N). The cytoplasm contains numerous mitochondria (m) Desmosomes (curved arrows) are seen connecting the cells.

(TEM, X3000).

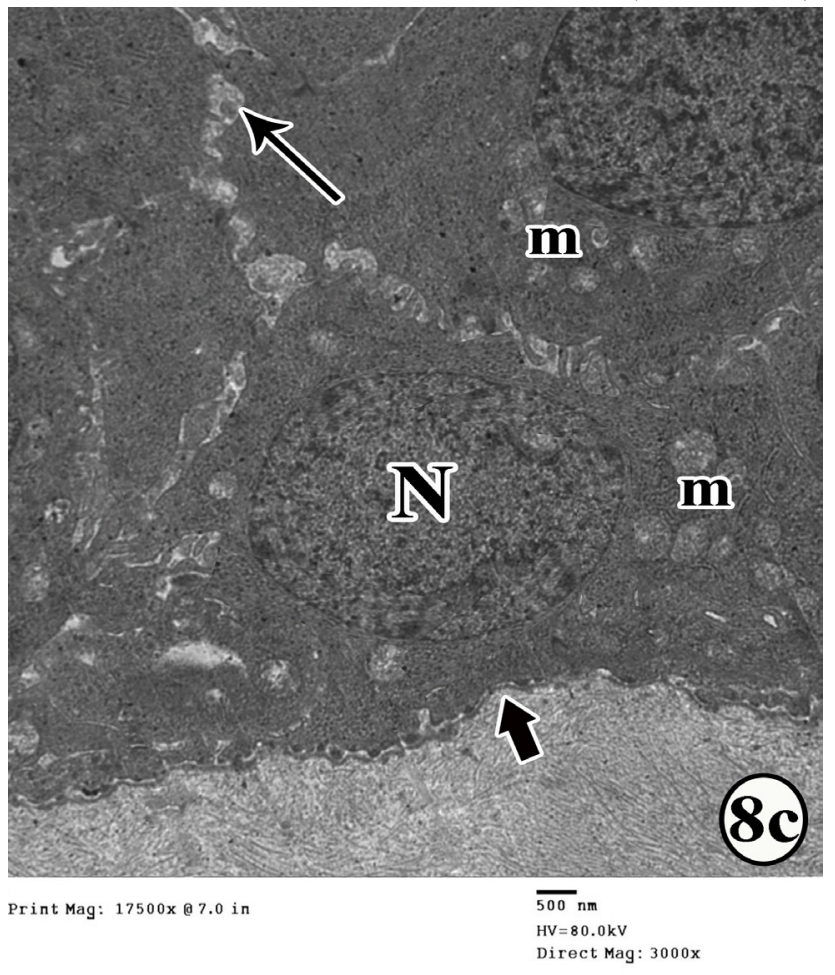

Fig. 8c: An electron micrograph of a rat cornea of group V showing cells of the basal layer with regular euchromatic nuclei $(\mathrm{N})$ and numerous mitochondria $(\mathrm{m})$ resting on a slightly irregular basement membrane (arrow). The cells are connected by desmosomes (curved arrows) separated by minimal intercellular spaces (thin arrow).

(TEM, X3000). 


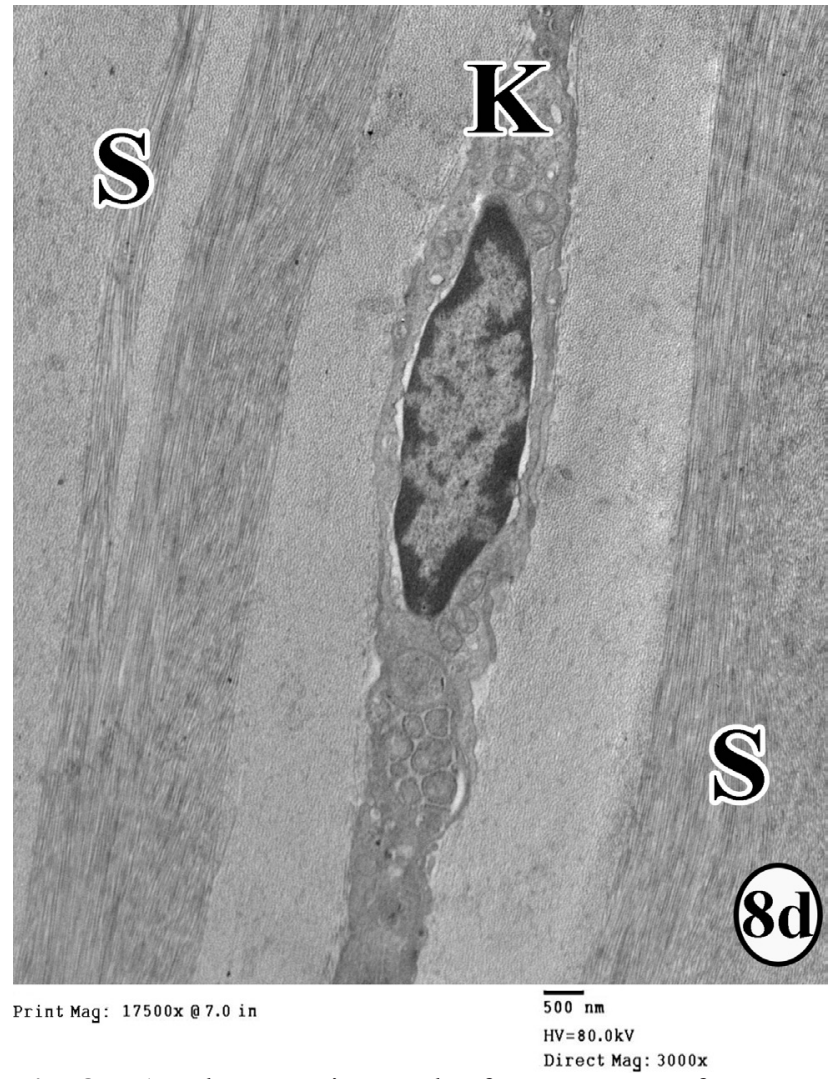

Fig. 8d: An electron micrograph of a rat cornea of group $\mathrm{V}$ showing regular orthogonal arrangement of the collagen fibrils of the stroma (S). Keratocytes $(\mathrm{K})$ appear spindle shaped with a euchromatic nucleus.

(TEM, X3000).

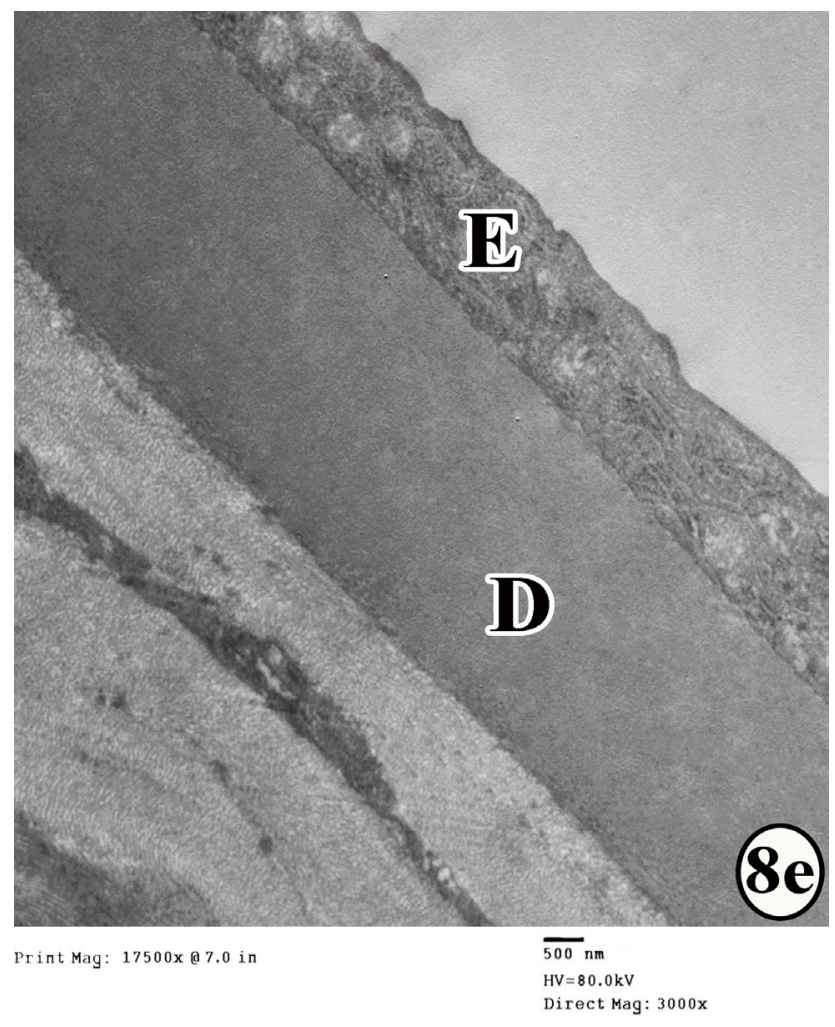

Fig. 8e: An electron micrograph of a rat cornea of group V showing homogenous Descemet's membrane (D) and endothelial cell (E).

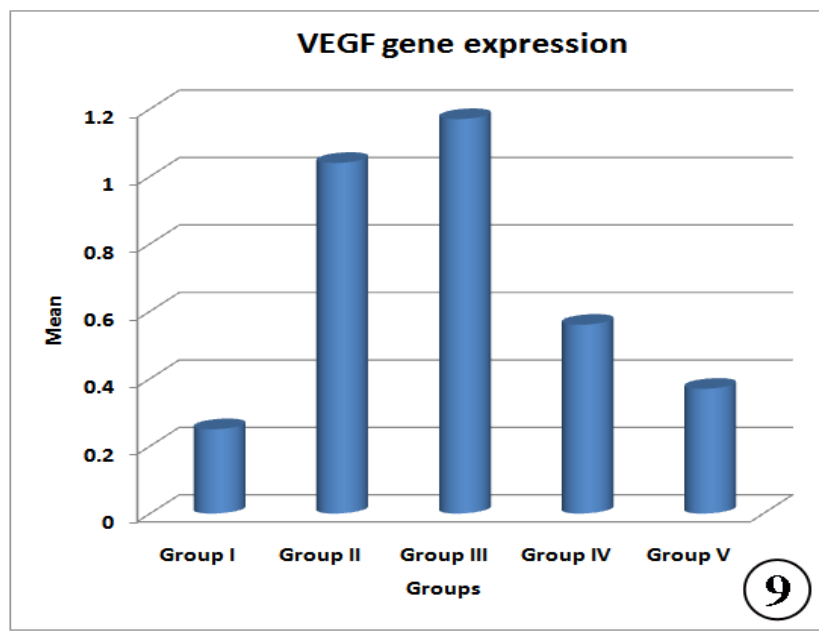

Fig. 9: A bar chart showing the mean VEGF gene expression of all groups.

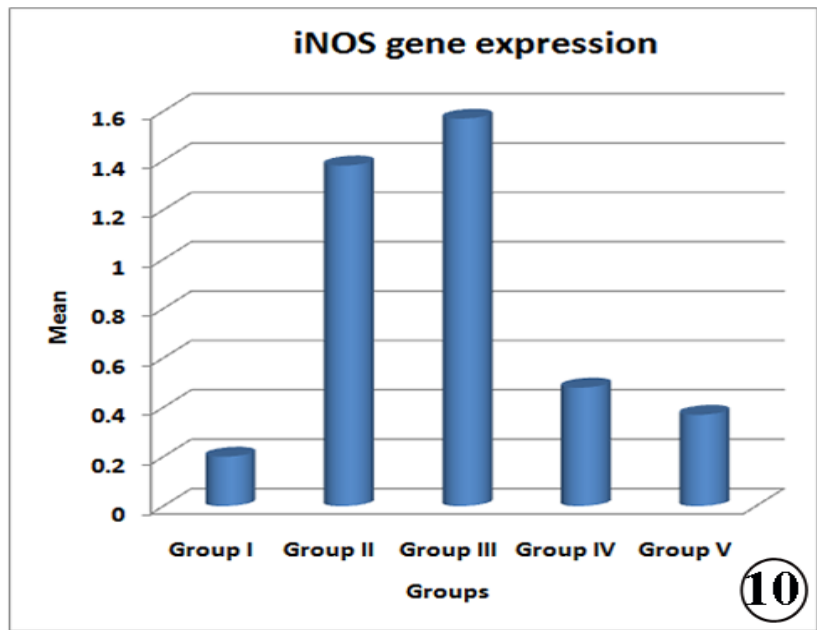

Fig. 10: A bar chart showing the mean iNOS gene expression of all groups.

\section{DISCUSSION}

A chemical burn is an ocular emergency that demands prompt and proper management. They frequently cause squeal which leads to blindness affecting the patients' mobility, independence and overall quality of life ${ }^{[24]}$.

The corneal ulcers induced by chemical alkali burns result in change of the $\mathrm{pH}$ of the surrounding tissue leading to ulceration, proteolysis and collagen synthesis defects. Alkalis cause saponification of cell membranes leading to damage of the tissues and release proteolytic enzymes as a part of an inflammatory response which leads to further damage ${ }^{[25]}$.

Rats in group II (corneal ulcer group), in the present study, were sacrificed three days after induction of corneal alkali burn to assess histological changes in corneas as corneal chemical burns manifest in four phases including immediate, acute, early repair and late repair phases. In the acute phase, epithelial regrowth started if there were enough amounts of 
undamaged limbal stem cells. Treatment should encourage the growth and preventing inflammation. Thus they must be treated in their acute phase to enhance re-epithelialization, reduce inflammation and limit further degeneration of the epithelium and stroma $^{[26]}$.

Group II in the current study revealed severe histological alterations of the corneas (epithelial desquamation, nuclear and cytoplasmic changes, disorganization of collagen fibrils, inflammatory cells infiltration, and degenerative changes of the endothelial cells, attenuation, and interruption of the Descemet's membrane) with significant increase in VEGF and iNOS compared to control group. In accordance with these findings, Ke et al., (2015) reported that on day 3 after corneal alkali burn, histological examination revealed corneal epithelial cells loss, bullous keratopathy, and multiple layers of stromal irregularly, sever inflammatory cell invasion and neovascularization within the stoma ${ }^{[27]}$.

In this study, rats of group III (recovery group) were sacrificed 28 days post corneal alkali burn to assess spontaneous recovery in the late repair phase. In cases of severe corneal damage with LSC depletion residual alterations result in irreversible visual diminution ${ }^{[28]}$.

Group III revealed thin epithelium, wide intercellular spaces and persistent nuclear and cytoplasmic changes. Disorganized collagen fibrils, numerous inflammatory cells, and degenerated keratocytes were still present in the stroma. Additionally, many dilated blood vessels were observed. Furthermore, endothelial cells were separated from the underlying Descemet's membrane. However, there was no significance difference in VEGF and iNOS compared to group II (ulcer group). In agreement with these findings, Suzuki et al., (2000) found that adherent's junctions and gap junctions were lost in corneal alkali burn due to remodeling of desmogleins of epithelial desmosomes. Also, Yao et al., (2012) demonstrated that chemical alkali burns lead to exposure of corneal basal layer due to necrosis and desquamation of corneal superficial layer. In addition, Jiang et al. (2013) reported that during the recovery phase, epithelial cells overlapped into denuded zones signifying attempts of re-epithelialization by epithelial migration from the healthy corneal epithelium to zones of epithelial defect. Basal epithelial cells proliferation encircling the defect could help in the reestablishment of normal multilayered architecture of the epithelium and in fixation of the newly regenerated epithelium to underlying connective tissue. Also, this was in agreement with the study of Bae et al., (2010) which revealed degeneration and necrosis of keratocytes with inflammatory cellular invasion in corneal alkali burn. Inflammatory cells were demonstrated to generate matrix metalloproteinases and diversity of proteases that broke up collagen fibers in corneal alkali burn, subsequently harming the normal corneal architecture and preventing the stromal healing leading to different degrees of corneal opacities with corneal inflammation after alkali burn ${ }^{[33]}$.

In agreement with these results, some researches exhibited corneal neovascularization 28 days after corneal alkali burn in rats as recorded in our research in group III. This occurred due to inflammation which initiated tissue hypoxia and subsequently leading to over-proliferation of the capillary endothelial cells. This happened because of expanded generation of angiogenic stimulators, (for example, VEGF) and diminished generation of angiogenic inhibitors, (for example, angiostatin). Also, these vessels could generate extreme reactions by their hyperpermeability, bringing about higher leakage of plasma, lipids, and plasma proteins. All these might penetrate into the corneal stroma, leading to corneal edema and corneal opacity. Also, edema might increase the interstitial pressure leading to stagnation with incomplete vessel obstruction. The subsequent decrease in corneal oxygenation would delayed wound regeneration and exacerbate the injury ${ }^{[34]}$.

In the current study, group IV and V (corneal ulcer + stem cells) showed improvement in all parameters (light microscope, electron microscope and gene expression studies) as shown by continuous and well organized stratified squamous epithelium, reconstructed corneal stromal arrangement, nearly normal keratocytes between orchestrated collagen fibers with no inflammatory cells invasion and a continuous layer of Descemet's membrane and endothelial cells compared with the control group. BM-MSCs also reduced the neovascularization effect by diminishing vascular endothelial growth factor (VEGF) after corneal alkali burn in rats of group IV and $\mathrm{V}$.

These findings are in agreement with Harkin et al., (2015) who reported that BM-MSCs enhanced epithelial healing. This occured through various ways by which the MSCs reconstructed the corneal injuries after corneal alkali burn by growth factors and cytokines secretions which regulated cell proliferation and signaling. Another research revealed that injured corneas treated with BM-MSCs demonstrated a significant improvement of epithelial defect closure exhibiting a normal multilayered epithelium with no intercellular spaces in epithelial cells compared with untreated eyes due to stem cell capacity to differentiate into various cell types. Also, the regenerated keratocytes secreted essential elements to keep the orthogonal arrangement of the stroma, as keratan-sulfate proteoglycans. They are important for developing and maintaining normal collagen 
interfibrillar spacing and the fibril breadth that required for corneal transparency ${ }^{[36]}$.

This improvement explained also by Giacomini et al., (2014). BM-MSC shielded the corneal endothelium from the oxidative stress brought about by free radicals $^{[37]}$. It repressed chemotaxis of leukocytes and phagocytosis of macrophages and discharge of free oxygen radicals through its immunomodulatory activity. The BM-MSCs secured the corneal epithelium and endothelium and were included in tissue morphogenesis.

In this study, PCNA expression was clearly highly expressed in basal epithelium and throughout the surface and depth of the epithelium in group IV and V. In agreement with these finding, Ye et al., (2006) demonstrated stem cell activity and the kinetics of cell proliferation during corneal alkali burn healing by utilizing stable cell cycle-regulated protein (PCNA) ${ }^{[38]}$. The MSCs stimulate the limbal stem cells proliferation, as proofed by PCNA expression. This proof demonstrates that the MSCs migrated into the injured cornea and exhibited a positive effect on the propagation of native corneal cell. The possible explanation of is that the engrafted MSCs in cornea may stimulate more limbal stem cells; these activated stem cells respond to the local particular environment created by inflammatory reaction and release cytokines from MSCs, gaining the capacity to propagate and differentiate. So the engrafted MSCs can enhance wound healing by stimulating and synergizing with native cell.

One of the real obstacles related with MSC therapy remains as there is no reasonable vehicle to convey MSCs to a distinct location. Essentially, MSCs for ocular surface regeneration can't be directly conveyed onto the injured eyes as a cell suspension ${ }^{[39]}$.

The corneas of group IV still suffered from some residual histological alterations while on the other hand, group V displayed corneas nearly normal and comparable to those of the control group. Group IV (corneal ulcer + MSCs on AM treated group) revealed that the intermediate layer was still irregular with few wide intercellular spaces, some nuclear and cytoplasmic degeneration, vacuolated keratocytes. The endothelial cells were relatively degenerated and contained many mitochondria with disrupted cristae. The VEGF and iNOS expression were significantly decreased. While in group V (corneal ulcer + MSCs on PRP treated group) in the current study revealed nearly normal corneal histological structure in comparable with that of the control group. The VEGF and iNOS gene expression significantly decreased in comparison with the corneal ulcer group.
In agreements with these findings, Meller et al., (2011) reported that amniotic membranes (AM) possessed several properties useful in the treatment for the ocular injury ${ }^{[40]}$. The AM reduce the inflammatory response and suppressed IL- $\alpha$ and IL1 $\beta$ in the epithelial cells by trapping and inducing apoptosis of inflammatory cells. In addition, tissue remodeling was reported with their use via stimulating apoptosis of $\mathrm{T}$ lymphocytes and regulating activated macrophages. Paolini et al., (2016) also revealed that AM acts as a scaffold for proliferation and differentiation due to its content of fibronectin, elastin, hyaluronic acid and collagen type I, III, IV, V and VI ${ }^{[41]}$. Also, various growth factors have been detected in cryopreserved AMs including epidermal growth factor and transforming growth factors which play a crucial role in the anti-scarring and anti-inflammatory effects of $\mathrm{AM}$, in addition to enhancing re-epithelialization and healing ${ }^{[42]}$.

Despite the fact that AM are the most common cell carrier for ocular surface reconstruction, some researchers reported that with severe ocular surface disease, the success rate of amniotic membrane in treating ulcers and/or a perforation was less than $20 \%$. As they hold the possible risk of infection transfer, variable tissue quality, and limited transparency, alternative seeding scaffolds have been proposed ${ }^{[43]}$.

Additionally, AMs contain contradicting biomolecules which may cause conflicting results on corneal healing. For example, IL-6 and IL-8 are proinflammatory cytokines while IL-10 and IL-1ra are anti-inflammatory. Furthermore, matrix metalloproteinases (MMPs) promote neovascularization. However, tissue inhibitors of metalloproteinases have the reverse role in inhibiting neo-vascularization. Prostaglandins may promote inflammation, but prostaglandin inactivating enzyme and secretory leukocyte inhibitor can suppress inflammation ${ }^{[44]}$.

While the improvement occurred in group $\mathrm{V}$ because PRP concentrates platelets in a small volume of plasma which contains a high concentration of important growth factors, cytokines, and cell adhesion molecules.

In accordance with these results, Stessuk et al., (2016) demonstrated that there were more than 15 growth factors present in the $\mathrm{PRP}^{[45]}$. These growth factors reside in the alpha granules of the platelets (50-80 per platelet). Platelet alpha granules are reservoirs of numerous growth factors and other proteins such as platelet-derived growth factor (PDGF), fibroblast growth factor (FGF), transforming growth factor- $\beta$ (TGF $\beta$ ), vascular endothelial growth factor (VEGF), and endothelial growth factor (EGF) 
which play a vital role in tissue regeneration. So PRP was effective in the healing of ulcers and may be used as a part of other procedures for reconstruction of the cornea.

PRP was activated in the present study by the addition of thrombin and calcium chloride to form a gel. Thrombin activation causes the release of growth factors, improving vascularity and promoting regeneration. PRP activation also leads to the release of a burst of growth factors into the surrounding tissue and maintains their sustained release ${ }^{[46]}$.

In vivo, MSCs activities are regulated by the molecular microenvironments that modulate their anabolic status. Thus, signaling factors in the microenvironment instruct MSCs to remain quiescent, proliferate, migrate, and/or differentiate. In this context, (Anitua et al., 2015) revealed that tfactors released by PRP promote the healing mechanisms of MSCs through microenvironment regulation ${ }^{[47]}$. Such factors include epidermal growth factor, that is a potent stimulator of epithelial proliferation and migration, exerts an antiapoptotic effect and stimulates extracellular matrix production, including fibronectin and hyaluronic acid.

Furthermore, PRP stimulates MSC proliferation, preserves MSCs multipotency and does not interfere with any lineage differentiation. PRP preserves the immune-privileged potential of MSCs and may delay the appearance of the senescent phenotype ${ }^{[48]}$.

\section{CONCLUSION}

In the current study, BM-MSCs enhanced the healing capacity of corneal alkali burns. Better results were observed when stems cells were loaded on PRP gel than AM. PRP gel provided growth factors and various proteins necessary in regeneration. It also promoted the healing mechanisms of BM-MSCs through regulation of their surrounding microenvironment. Additionally, PRP gel stimulated proliferation and preserved the immune privilege of BM-MSCs. Thus the use of PRP gel is recommended as a vehicle for BM-MSCs in treatment of corneal alkali burns to avoid long term complications and visual impairment.

\section{CONFLICT OF INTEREST}

There are no conflicts of interest.

\section{REFERENCES}

1. Robaei D and Watson S: Corneal blindness, a global problem. Clin. Exp. Ophthalmol. (2004) 42: 213 - 214.

2. Giacomini $C$, Ferrari G, Bignami F and Rama P: Alkali burn versus suture induced corneal neovascularization in C57BL/6 mice: An overview of two common animal models of corneal neovascularization. Exp. Eye Res. (2014) 121: 1 - 4.

3. Hsu C, Chang H, Lin T, Hung K, Chien K, Chen S, Chen $\mathrm{S}$ and Chen Y: Corneal neovascularization and contemporary antiangiogenic therapeutics. J. Chin. Med. Assoc. (2015) 78: 323- 330.

4. Kolli S, Ahmad S, Mudhar H, Meeny A, Lako M and Figueiredo F: Successful application of ex vivo expanded human autologous oral mucosal epithelium for the treatment of total bilateral limbal stem cell deficiency. Stem Cells (2014) 32: 2135- 2146.

5. Lee J, Jeong H, Kim M and Wee W: Bone marrowderived mesenchymal stem cells affect immunologic profiling of interleukin -17- secreting cells in a chemical burn mouse model. Korean J. Ophthalmol. (2014) 28: 246- 256

6. Chan A, Hertsenberg A, Funderburgh M, Mann M, Du Y, Davoli K, Mich Basso J, Yang L and Funderburgh J: Differentiation of human embryonic stem cells into cells with corneal keratocyte phenotype. PLoS One (2014) 8: e56831.

7. Cejkova J, Trosan P, Cejka C, Lencova A, Zajicova A, Javorkova E, Kubinova S, Sykova E and Holan V: Suppression of alkali induced oxidative injury in the cornea by mesenchymal stem cells growing on nanofiber scaffolds and transferred onto the damaged corneal surface. Exp. Eye Res. (2013) 116: 312- 323.

8. Mansour M: Penetrating keratoplasty for keratoconus: Visual and graft survival outcomes. International Journal of Health Sciences (2013) 7: 67-74.

9. Jiang TS, Cai L, Ji WY, Hui YN, Wang YS and Hu D: Reconstruction of the corneal epithelium with induced marrow mesenchymal stem cells in rats. Mol. Vis. (2010) 16: 1304-1316.

10. Reinshagen H, Auw-Haedrich C, Sorg RV, Boehringer D, Eberwein, P, Schwartzkopff J, Sundmacher R and Thomas R: Corneal surface reconstruction using adult mesenchymal stem cells in experimental limbal stem cell deficiency in rabbits. Acta Ophthalmologica (2011) 89: 741-748.

11. Feng Y, Borrelli M, Reichl S, Schrader S and Geerling G: Review of Alternative Carrier Materials for Ocular Surface Reconstruction. Curr. Eye Res. (2014) 39 (6): 541-552.

12. Arnalish F, Rodriguez AE, Luque-Rio A and Alio JL: Solid Platelet Rich Plasma in Corneal Surgery. Opthalmol. Ther. (2016) 5 (1):31-45. 
13. Ahmed SK, Soliman AA, Omar SM and Mohammed WR: Bone Marrow Mesenchymal Stem Cell Transplantationin a Rabbit Corneal Alkali Burn Model (A Histological and Immune Histo-chemical Study). Int. J. Stem Cells (2015) 8: 1-10.

14. Abdel Aziz MT, El Asmar MF, Atta HM, Mahfouz S, Fouad HH, Roshdy NK, Rashed LA, Sabry D, Hassouna AA and Taha FM: Efficacy of mesenchymal stem cells in suppression of hepatocarcinorigenesis in rats: possible role of Wnt signaling. J. Exp. Clin. Cancer Res. (2011) 30:49-60.

15. Vongsakul S, Tuntivanich $\mathrm{P}$, Sirivaidyapong S and Kalpravidh M: Canine Amniotic Membrane Transplantation for Ocular Surface Reconstruction of Created Deep Corneal Ulcers in Dogs. Thai J. Vet. Med. (2009) 39(2): 135-144.

16. Zhang ZY, Teoh SH, Chong MS, Schantz JT, Fisk NM, Choolani MA, and Chan J: Superior Osteogenic Capacity for Bone Tissue Engineering of Fetal Compared with Perinatal and Adult Mesenchymal Stem Cells. Stem Cells (2009) 27 (1):126-137.

17. Radcliffe CH, Flaminio MJ and Fortier LA: Temporal analysis of equine bone marrow aspirate during establishment of putative mesenchymal progenitor cell populations. Stem Cells Develop (2010) 19 (2):269-282.

18. Yin W, Qi X, Zhang Y, Sheng J, Xu, Z and Tao S: Advantages of pure platelet-rich plasma compared with leukocyte- and platelet-rich plasma in promoting repair of bone defects. J. Transl. Med. (2016) 14: (73) doi:10.1186/s12967-016-0825-9.

19. Le Nihouannen D, Saffarzadeh A, Aguado E, Goyenvalle E, Gauthier O, Moreau F, Pilet P, Spaethe R, Daculsi G and Layrolle P: Osteogenic properties of calcium phosphate ceramics and fibrin glue based composites. J. Mater Sci. Mater Med. (2007) 18 (2):225-235.

20. Bancroft JD and Layton C. The hematoxylin and eosin [chapter 10]. In: Suvarna SK, Layton C, Bancroft JD, editors. Theory and practice of histological techniques. 7th ed. Philadelphia: Churchill Livingstone of Elsevier; 2013. pp. 172-186.

21. Jackson P, and Blythe D. Immunohistochemical techniques [chapter 18]. In: Suvarna SK, Layton $\mathrm{C}$, Bancroft JD, editors. Theory and practice of histological techniques. 7th ed. Philadelphia: Churchill Livingstone of Elsevier; 2013. pp. 381-426.

22. Kalleny $\mathrm{N}$ and Soliman N: Light and electron microscopic study on the effect of topically applied hyaluronic acid on experimentally induced corneal alkali burn in albino rats. Egypt. J. Histol. (2011) 34: 829-848 77 .

23. Livak J and Schmittgen D: Analysis of relative gene expression data using real-time quantitative PCR and the 2(-Delta Delta C(T)) Method. Methods (2001) 25:402-408.

24. Eslani M, Baradaran-Rafii A, Movahedan A, and Djalilian R: The Ocular Surface Chemical Burns. J. Opthalmol. (2014):196827.

25. Singh P, Tyagi M, Kumar Y, Gupta KK and Sharma PD: Ocular chemical injuries and their management, ocular surface anatomy and visual function. Oman Journal of Ophthalmology (2013) 6(2):83-86.

26. Hamill CE, Bozorg S, Peggy Chang HY, Lee H, Sayegh RR, Shukla AN and Chodosh J: Corneal alkali burns: a review of the literature and proposed protocol for evaluation and treatment. Int. Ophthalmol. Clin. (2013)53 (4):185-94.

27. Ke Y, Wu Y, Cui X, Liu X, Yu M, Yang C and Li X: Polysaccharide Hydrogel Combined with Mesenchymal Stem Cells Promotes the Healing of Corneal Alkali Burn in Rats. PLoS One (2015)10(3): e0119725.

28. Trief D, Chodosh J, Colby $\mathrm{K}$ and Griffiths $\mathrm{D}$ : Chemical (Alkali and Acid) Injury of the Conjunctiva and Cornea. American Academy of Ophthalmology (2017).

29. Suzuki K, Tanaka T, Enoki $M$ and Nishida $T$ : Coordinated reassembly of the basement membrane and junctional proteins during corneal epithelial wound healing. Invest. Ophthalmol. Vis. Sci. (2000) 41: $2495-2500$

30. Yao L, Li ZR, Su WR, Li YP, Lin ML, Zhang WX, Liu Y, Wan Q and Liang D: Role of mesenchymal stem cells on cornea wound healing induced by acute alkali burn. PLoS One (2012) 7 (2):e30842.

31. Jiang T, Cai L, Ji Y, Hui N, Wang S, Hu D and Zhu J: Reconstruction of the corneal epithelium with induced marrow mesenchymal stem cells in rats. Mol. Vis. (2010) 16:1304-1316.

32. Bae S, Park C, Choi JC, Poo H, Kim CJ and Sung MH. Effects of ultra-high molecular weight poly- $\gamma$ glutamic acid from Bacillus subtilis (chungkookjang) on corneal wound healing. J. Microbiol. Biotechnol. (2010) 20 (4):803-808.

33. Pattamatta U, Willcox M, Stapleton F, Cole N and Garrett Q: Bovine lactoferrin stimulates human 
corneal epithelial alkali wound healing in vitro. Invest. Ophthalmol. Vis. Sci. (2009) 50 (4):1636-1643.

34. Ghazaryan E, Zhang Y, He Y, Liu X, Li Y, Xie $\mathrm{J}$ and $\mathrm{Su}$ G.:Mesenchymal stem cells in corneal neovascularization: Comparison of different application routes. Mol. Med. Rep. (2016) 3104 -3112.

35. Harkin DG, Foyn L, Bray LJ, Sutherland AJ, Li FJ and Cronin BG.: Concise reviews: Can mesenchymal stromal cells differentiate into corneal cells? A systematic review of published data. Stem Cells (2015) 33 (3):785-791.

36. Holan V, Trosan P, Cejka C, Javorkova E, Zajicova A, Hermankova B, Chudickova M and Cejkova J: A Comparative Study of the Therapeutic Potential of Mesenchymal Stem Cells and Limbal Epithelial Stem Cells for Ocular Surface Reconstruction. Stem Cells Transl. Med. (2015) 4(9):1052-1063.

37. Giacomini C, Ferrari G, Bignami F and Rama P: Alkali burn versus suture-induced corneal neovascularization in C57BL/6 mice: An overview of two common animal models of corneal neovascularization. Exp. Eye Res. (2014) 121:1-4.

38. Ye J, Yao K and Kim JC : Mesenchymal stem cell transplantation in a rabbit corneal alkali burn model: engraftment and involvement in wound healing. Eye (2006) 121, 482-490.

39. Prabhasawat P, Ekpo P, Uiprasertkul M, Chotikavanich $\mathrm{S}$ and Tesavibul N: Efficacy of cultivated corneal epithelial stem cells for ocular surface reconstruction. Clin. Ophthalmol. (2012) 6: 1483-1492.

40. Meller D, Pauklin M, Thomasen H, Westekemper H and Steuhl K: Amniotic membrane transplantation in the human eye. Dtsch. Arztebl. Int. (2011) 108(14): 243-248.

41. Paolin A, Cogliati E, Trojan D, Griffoni C, Grassetto A, Elbadawy M and Ponzin D: Amniotic membranes in ophthalmology: long term data on transplantation outcomes. Cell Tissue Bank (2016)5 17 (1) 1-58.

42. Gupta A, Kedige SD and Jain K: Amnion and chorion membranes: Potential stem cell reservoir with wide applications in periodontics. Int. J. Biomater. (2015) 274082.

43. Vazirani J, Basu S, Kenia H, Ali MH, Kacham S, Mariappan I and Sangwan V.: Unilateral partial limbal stem cell deficiency: contralateral versus ipsilateral autologous cultivated limbal epithelial transplantation. Am. J. Opthalmol. (2014) 157(3): 584-590.e2-590.e2.

44. Tsuno H, Arai N, Sakai C, Okabe M, Koike C, Yoshida T, Nikaido T and Noguchi M: Intraoral application of hyperdry amniotic membrane to surgically exposed bone surface. Oral Surg. Oral Med. Oral Pathol. Oral Radiol. (2014)117(2):e83-7.

45. Stessuk T, Puzzi MB, Chaim EA, Alves PC, de Paula EV, Forte A, Izumizawa JM, Oliveira CC, Frei F and Ribeiro-Paes JT: Platelet-rich plasma (PRP) and adipose-derived mesenchymal stem cells: stimulatory effects on proliferation and migration of fibroblasts and keratinocytes in vitro. Arch. Dermatol. Res. (2016) 308:511-520.

46. Arnalich F, Rodriguez AE, Luque-Rio A and Alio JL: Solid Platelet Rich Plasma in Corneal Surgery. Opthalmol. Ther. (2016)5(1):31-45.

47. Anitua E, Muruzabal F, Tayebba A, Riestra A, Perez VL, Merayo-Lloves J and Orive G: Autologous serum and plasma rich in growth factors in ophthalmology: preclinical and clinical studies. Acta Ophthalmol. (2015) 93:e605-614.

48. Rubio-Azpeitia E and Andia I: Partnership between platelet-rich plasma and mesenchymal stem cells: in vitro experience. Muscles Ligaments Tendons J. (2014) 4(1):52-62. 
الملخص العربى

الدور العلاجى المحتمل للخلايا الجذعية المحملة على ناقلين مختليفين (الغشاء الذي يحيط بالجنين و جل هلام البلازما الغتى بالصفائح الدموية) فى حروق القزنية القلوية المستحدثة تجريبيا فى الجرذان

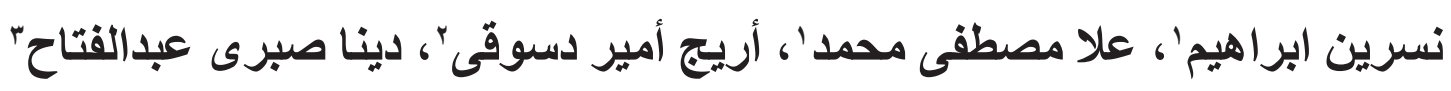

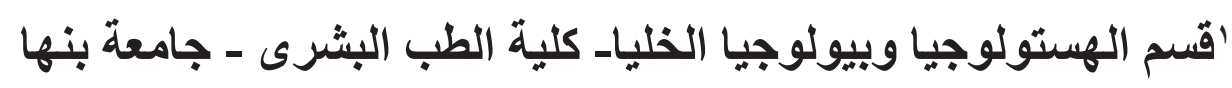

بقسم الهستولوجيا وبيولوجيا الخليا- كلية الطب البشرى - جامعة الزقازيق

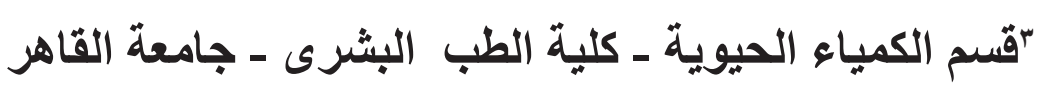

المقدمة: تعتبر الحروق القلويه للقرنيه واحده من الطواريء الثائعه في امراض العيون التي قد تؤدي الي فقدان البصر الدائم. و علي الرغم من التقدم الكبير المحرز في علاج مثل هذه الحالات ، الا انه لايزال هناك تحديا كبير ا في اعادة الهيكله التركيبيه و الوظيفيه لأنسجة القرنية. وقد أثتبت الخلايا الجذعيه المستخلصه من النخاع العظمي فاعليتها في أعاده بناء القرنية مما يعزز

$$
\text { من شفاؤها. }
$$

الهدف من الدراسة: تقييم القدره العلاجيه للخلايا الجذعيه المحمله علي حاملين بيولوجيين مختلفين الاول هو الغشاء الاميني الذي يحيط الجنين بعد معالجته و الاخر هو هلام البلازما الغني بالصفائح الدموية في علاج الحروق القلويه للقرنيه. المواد وطرق البحث: تم تقسيم خمسين فأر ا عشو ائيا الي خمس مجموعات متساوية: المجموعه الأولي (المجموعة الضابطة). المجمو عه الثانية: نم إحداث قرحه في قرنيه العين اليمني بإحر اقها بمادة هيدروكسيد الصوديوم ثم ذبحت الفئران بعدها بثلاث أيام. المجموعة الثالثة: بعد احداث حرق القرنيه بماده هيدروكسيد الصوديوم ثم ذبحت الفئران بعد 28 يوم ـالمجمو عه الر ابعة:

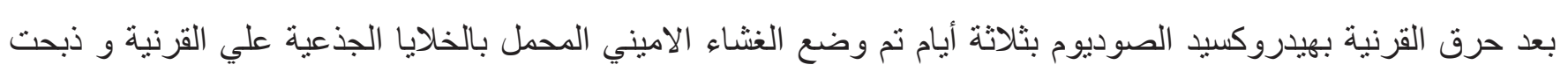

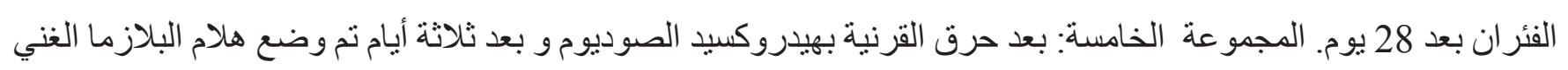
بالصفائح الدموية و المحمل بالخلايا الجذعية علي القرنية ثم ذبحت الفئر ان بعد 28 يو م. وبعد ذلك تم تجهيز عينات القرنية لفحصها

$$
\text { بالميكر سكوب الضوئي و الالكتروني. }
$$

النتائج: أثنتت نتائج هذه الدر اسة تحسنا في تركيب القرنية في المجمو عتين الرابعة و الخامسة وكان التحسن بشكل ملحوظ في المجمو عه الخامسة المعالجة بالخلايا الجذعية المحمله علي هلام البلازما الغني بالصفائح الدموية. 